\title{
PEMANFAATAN MEKANISME ASEAN DALAM PENYELESAIAN MASALAH PERBATASAN THAILAND
}

\author{
C.P.F. Luhulima \\ cpfluhu5@yahoo.com \\ Lembaga Ilmu Pengetahuan Indonesia
}

\begin{abstract}
Thailand's borders with Myanmar, Laos, Cambodia and Malaysia have been established through a mapping process within the framework of the Treaty of Westfalpha. Since the England and France left Southeast Asia after World War II, Thailand questioned its borders with its neighbouring countries and since then the border issue between Thailand and her neighbours became the major issue. The attempts to resolve the border conflict between Thailand and Myanmar have been conducted through "constructive engagement", and through her policy of "changing battlefields to market places". The ASEAN approach has been employed in her border conflict with Cambodia. Cambodia's attempt to involve the UN Security Council has been responded by the Council to involve ASEAN in its resolution. The failure of the ASEAN approach made Cambodia to submit the issue to the ICJ in The Hague in April 2011. On November 11, 2013 ICJ decided that Preah Vihear and its surrounding area belong to Cambodia. The source of the conflict with Malaysia was not primarily about border, but it was a political complaint. The rebellion at the border area will thus not terminate until the Thai authorities understand the complaints of the Muslim-Malays at the border area. The ASEAN mechanism to resolve the inter-state conflict consists of bilateral, trilateral approaches, through the High Council and the United Nations. The application of steps between Thailand and its neighbours are the bilateral, trilateral steps and the one through the International Courtof Justice in The Hague.
\end{abstract}

Keywords: Thailand, Myanmar, Malaysia, Kamboja, ASEAN, Dispute Settlement Mechanism

\begin{abstract}
Abstrak
Batas Kerajaan Thailand dengan Myanmar, Laos, Kamboja dan Malaysia dibentuk melalui proses pemetaan di dalam kerangka Traktat Westfalia. Ketika Inggris dan Prancis mengundurkan diri sesudah Perang Dunia II, Thailand mempersoalkan perbatasannya dengan negara-negara tetangganya, sehingga perbatasan menjadi pokok permasalahan. Sengketa dengan Myanmar diupayakan penyelesainnya melalui "constructive engagement", dan dengan kebijakannya "changing battlefields to market places". Pendekatan ASEAN digunakan untuk menyelesaikan konflik dengan Kamboja. Pelibatan Dewan Keamanan PBB dijawab dengan meminta kedua belah pihak melibatkan ASEAN. Kegagalan pendekatan ASEAN menyebabkan Kamboja mengajukan kasus ini ke ICJ pada April 2011. Pada 11 November 2013 Mahkamah Internasional di Den Haag memutuskan bahwa Candi Preah Vihear dan wilayah sekitarnya adalah milik Kamboja. Permasalahan dengan Malaysia bukanlah masalah perbatasan antara kedua negara melainkan keluhan politik, sehingga pemberontakan di perbatasan tidak akan berakhir sampai penguasa Thailand memahami keluhan orang-orang Muslim-Melayu di perbatasan. Mekanisme ASEAN untuk mengatasi sengketa antarnegara anggota terdiri dari langkah bilateral, trilateral, melalui pembentukan Dewan Tinggi dan melalui lembaga hukum PBB. Yang di-terapkan dalam kasus sengketa perbatasan antara Thailand dan negara tetangganya ialah pendekatan bilateral dan trilateral serta melalui Lembaga Peradilan PBB.
\end{abstract}

Kata kunci: Thailand, Myanmar, Malaysia, Kamboja, ASEAN, Mekanisme Penyelesaian Perselisihan 


\section{Pendahuluan}

Masalah perbatasan Thailand dengan negara-negara tetangganya, Myanmar, Laos, Kamboja dan Malaysia mulai ketika negara-negara kolonial Inggris dan Prancis mulai menentukan wilayah kekuasaannya di Birma dan Indochina pada akhir abad ke-19 dan permulaan abad ke-20. Sebelum abad kesembilanbelas, kedaulatan yang bertumpah-tindih (overlapping or multiple sovereignties) sangatlah umum di Siam. Negara-negara kecil membayar upeti kepada satu atau dua junjungan (overlord) atau raja tanpa kehilangan kedaulatan mereka sendiri. Wilayah yang tidak ada yang menuntut kedaulatan atasnya juga ada. Pembentukan Siam modern, sebagai salah satu akibat dari imperialisme Eropa, menuntut penggantian konsep-konsep kedaulatan teritorial yang konvensional dengan konsep politik yang baru yang sekaligus menuntut perumusan kedaulatan dan nasion. Salah satu tuntutan itu adalah penciptaan batas-batas yang jelas dan yang tidak boleh dilanggar. Pembuatan peta memainkan peran yang sangat penting dalam proses ini. Khususnya bagi Siam, "Siamese nationhood today has, to a considerable extent, emerged through the mapping of Siam."1 Kerajaan Thailand, yang menggantikan Kerajaan Siam sejak 1939, dibentuk melalui proses pemetaan ini.

Perbedaan antara konsep kedaulatan Siam abad kesembilanbelas dan konsep dunia Barat tentang nasion (nationhood) tercermin dalam pertukaran nota diplomatik yang terjadi antara Siam dan Inggris di babak pertama abad kesembilanbelas, ketika Inggris mulai memperluas kekuasaannya dari India ke Burma. Tahun 1824, Inggris menundukkan bagian selatan Burma dan menye- butnya British Tenasseerim Province. Perbatasan dengan Siam lalu menjadi masalah bagi Inggris. East India Company kemudian mengutus Captain Henry Burney, kepala perwakilannya, untuk meminta pihak Siam merundingkan perbatasan antara wilayah Inggris yang baru dengan Siam. Mahkamah Peradilan Siam tidak tertarik dengan masalah perbatasan. Lembaga Siam ini menganggap bahwa tidaklah mungkin menetapkan perbatasan antara Siam dan Burma. Tetapi Inggris tetap menuntut penentuan batas itu Peradilan Siam lalu menetapkan agar supaya Inggris mencari tahu dari penduduk setempat, di daerah perbatasan Mergui, Tavoy and Tenasserim apa yang mereka tahu tentang wilayah yang berbatasan dan biarkan mereka menunjukkan wilayah-wilayah yang berbatasan dan biarkan mereka pula yang menentukan perbatasan antara wilayah Inggris dan Siam. ${ }^{2}$

Bagi Burney, pengertian bahwa perbatasan ditentukan oleh penduduk setempat tidak masuk akal. Tetapi bagi orang Siam, penilaian lokal merupakan satu-satunya penilaian yang masuk akal, karena "the boundaries between the Siamese and the Burmese consisted of a tract of mountains and forests, which is several miles wide and which could not be said to belong to either nation". 3

Ketika, di tahun 1826, perjanjian tentang perbatasan akhirnya ditandatangani antara Siam dan Inggris, kompromi yang paling baik yang dapat diperoleh Burney ialah pemasukan suatu nota yang menyatakan apabila salah satu pihak menyangsikan perbatasan manapun, "it should depute some officials and people from the frontier posts to inquire and settle mutual

\footnotetext{
${ }^{2}$ Ibid.

${ }^{3}$ Ibid
}

\footnotetext{
'Thongchai Winichakul, "Siam Mapped. The Making of Thai Nationhood", The Ecologist, Vol 26, No. 5, September/October 1996, h. 215
} 
borders in a friendly manner". ${ }^{4}$ Dengan sangat tepat Thongchai Winichakul mengatakan:

Clearly a "boundary" as understood by the British, on the one hand, and their Siamese counterparts, on the other, was a similar thing - but not the same. ${ }^{5}$

Bagi Siam perbatasan berarti wilayah atau distrik perbatasan, bukan garis. "They do mean a limit, but a limit as an extremity without a clear-cut edge and without the sense of division between two realms or powers." Bagi Inggris, batas tidak saja berarti suatu garis, melainkan juga kedaulatan teritorial yang eksklusif dan mutlak. Bagi politik Siam sebelum abad ke sembilanbelas kedaulatan itu tumpangtindih sifatnya, tidak jelas garis bentuknya. Di sinilah terletak perbedaan interpretasi tentang wilayah perbatasan dan garis perbatasan: wilayah perbatasan ialah wilayah yang tidak jelas batasannya dan garis perbatasan ialah suatu garis pembagi antara dua wilayah yang bersentuhan, wilayah yang jelas garis-garis pembatasannya.

Menjelang akhir abad kesembilanbelas, pemerintah di Bangkok mulai menerapkan konsep perbatasan Barat. Banyak elit Siam sudah memahami konsep-konsep geografi politik modern termasuk pengertian garis batas dan perbatasan serta kedaulatan teritorial yang eksklusif.

The ruling circle was now concerned to secure every bit of soil - the land which their ancestors has never worried about and had given away to other kingdoms as gifts. Sovereignty would now prevail over territory rather than over a governed town and its ruler. ${ }^{6}$

${ }^{4}$ Ibid.

${ }^{5}$ Ibid., h. 216

${ }^{6}$ Ibid. h. 218
Dalam menata perbatasan, Inggris bergerak dari barat dan Perancis dari timur, sedangkan Siam bergiat untuk menundukkan, mengamankan dan mencaplok negara-negara pinggiran ke dalam kedaulatan teritorialnya yang eksklusif - kendatipun mereka sadar bahwa sesuai dengan konsep pembayar upeti wilayah itu sebetulnya tidak merupakan milik Siam. Perbedaan dengan perlindungan yang diberikan sebelumnya sebagai junjungan kini dilakukan dengan mekanisme pengendalian perbatasan modern: kekuatan militer, administrasi, demarkasi perbatasan dan pemetaan.

Sejak pertengahan 1880an, kebutuhan akan pembuatan peta meningkat cepat, bukan karena pembangunan infrastruktur, melainkan untuk mengintegrasi negara-negara pinggiran ke dalam kerajaan Siam. ${ }^{7}$

The ultimate conqueror was the modern discourse of mapping. Without military force, mapping was inadequate to claim a legitimate space. But military presence was always legitimized and substantiated by a map. Mapping and military force became a single set of mutually reinforcing technologies to exercise power over space.

Dengan demikian,

A new "geobody" - that of Siam was thus established, its domain and its peoples determined not by a common culture, language or religion but by the boundary lines laid down as a result of the encounter between the European imperial powers and the Siamese court in the nineteenth and early twentieth centuries. The Siamese authorities then went on to attempt to engender a sense of nationhood among the people under their domain. $^{8}$

\footnotetext{
${ }^{7}$ Ibid.

${ }^{8}$ Ibid., h. 219
} 
Sesudah kemerdekaan Myanmar tercapai pada tahun 1948, Thailand (pengubahan nama dari Siam ke Thailand terjadi pada 1939) mulai mempersoalkan garis batas yang disetujuinya dengan pihak Inggris. Sejak itu garis perbatasan menjadi pokok permasalahan antara kedua negara, yang diperbesar oleh pemberontakan etnis di Myanmar melawan Tatmadaw, angkatan bersenjata Myanmar, dengan dukungan Thailand, serta imigrasi ilegal dan perdagangan manusia serta masuknya obat-obat terlarang yang berkelanjutan ke Thailand. ${ }^{9}$

Tetapi, Thailand sendiri juga berperan aktif dalam meningkatkan konflik bersenjata dengan Myanmar. Untuk menghadapi ancaman Myanmar, Thailand menyalurkan senjata dan bantuan-bantuan lain kepada pemberontak-pemberontak etnis di daerah perbatasan di utara Thailand. Di sinilah mulai kebijakan negara penyangga Thailand, kebijakan yang mendukung minoritas-minoritas etnis Myanmar yang "anti-Rangoon dan anti-komunis" di sepanjang perbatasan dengan Myanmar.“They represented bulwarks for Thailand against any forseeable Burmese menace in the form of physical and ideological intrusions." 10

Kebijakan penyangga Thailand
ini dan dukungannya kepada
kelompok-kelompok minoritas di per-
batasan antara kedua negara me-
ningkatkan skala konflik bilateral dan
terus meningkatkan saling permusuhan
dan kebencian yang berakar dalam
sekali dalam sejarah kedua bangsa ini.

\footnotetext{
${ }^{9}$ Kavi, op.cit., h. 119

${ }^{10}$ Pavin Chachavalpongpun, "Thailand-Myanmar Relations: Old Animosity in a New Setting", N. Ganesan dan Ramses Amer, International Relations in Southeast Asia. Between Bilateralism and Multilateralism, (Singapore: Institute of Southeast Asia Studies, 2010), h. 119
}

\section{Kebijakan "Constructive Engagement" Thailand dan ASEAN}

Di samping kebijakan penyangganya, Thailand juga menjalankan kebijakan pelibatan konstruktifnya (constructive engagement) terhadap Myanmar sejak pemerintah Chatichai Chunawan, yang memerintah dari Agustus 1988 sampai Februari 1991. Pencetusan istilah "constructive engagement" dilakukan menteri luar negeri Thailand, Arsa Sarasin, pada 1991. Pencanangan Chatichai Choonavan tentang kebijakan "changing battlefields to market places" memperlihatkan bahwa politik regional Thailand bergeser dari keamanan menuju ke pengembangan dan kerjasama ekonomi, dengan Myanmar dan dengan negaranegara Indochina. Jadi, ketika masyarakat internasional masih mengutuk kepemimpinan militer Myanmar bagi pelanggaran hak azasi manusia, Thailand membuka hubungan yang lebih dekat dengan rejim penguasa Myanmar, yang pada waktu itu masih disebut State Law and Order Restoration Council (SLORC) dengan mengembangkan kebijakan pelibatan konstruktif. Pemerintah-pemerintah Thai kemudian menyadari bahwa keuntungan dari kebijakan ini ialah keamanan dan kegiatan perdagangan di daerah perbatasan yang terus meningkat yang menguntungkannya, sehingga Thailand sadar bahwa ia memang tidak dapat bertetangga dengan suatu negara yang bermusuhan dengannya. ${ }^{11}$

Setahun kemudian, Jenderal Chavalit Yongchalyut memetik buah dari inisiatifnya, ia mendapatkan konsesi sumber daya alam yang sangat menguntungkan, kayu gelondongan, ikan dan hak eksplorasi dan eksploatasi

\footnotetext{
${ }^{11}$ Aung Saw, "ASEAN-Burma Relations". Challenges to Democratisation in Burma, $\mathrm{h}$.

42,http://www.idea.int/asia pacific/burma/upload/chap 1.pdf
} 
sumber mineral di Myanmar. Perkembangan ini memperkecil jurang permusuhan di antara Thailand dan Myanmar. Hubungan antara Thailand dan Myanmar berangsur bergeser, dari permusuhan dan persengketaan perbatasan menjadi kerjasama di bidang ekonomi. Myanmar mempunyai sumber daya alam yang murah dalam jumlah yang besar sekali yang diiginkan oleh negara-negara ASEAN, khususnya kayu, gas alam dan sumber daya mineral. Marvin Ott melihat sektor kayu gelondongan sebagai daya tarik utama Myanmar: "As the rest of the region's forests are systematically exploited and despoiled, Burma's still large (but rapidly diminishing) stands of tropical hardwoods have become a magnet."12 Banyak perusahaan ASEAN yang mempunyai hubungan langsung dengan pimpinan politik Myanmar melakukan investasi di negeri ini.

Istilah pelibatan konstruktif Myanmar tidak pernah dijelaskan. Bagi Aung Saw, pengertian dasarnya ialah "melibatkan dan membangun hubungan dengan Myanmar" dan bukan "mengabaikan dan mengisolasinya". Lebih luas lagi, pelibatan konstruktif dapat dilihat sebagai reaksi atas perubahan struktur keamanan regional wilayah Pasifik "and the complexities of ASEAN members' quest to sustain economic growth in the face of investment flight and the threat of regional trade blocs". ${ }^{13}$ Tetapi perubahan sikap ASEAN terhadap Myanmar tidak hanya ditanggapi dari konteks yang lebih luas ini, melainkan juga dari perubahan politik yang terjadi di Myanmar sendiri, sejak pemberontakan rakyat dan tantangannya terhadap kekuasaan Ne Win pada 1988. Myanmar

\footnotetext{
${ }^{12}$ Marvin Ott, "From Isolation to Relevance: Policy Considerations" in Burma: Prospects for

Democratization, Washington: Brookings Institute Press, 1998 , h. 73

${ }^{13}$ Aung Saw, op. cit., h. 37
}

kemudian melaksanakan perubahanperubahan dalam sistem ekonomi dan hubungan luar negerinya, yang sekaligus membuka Myanmar kepada dunia yang mencakup pembukaan hubungannya dengan China dan ASEAN. ${ }^{14}$

Pada lain pihak, jawaban ASEAN atas munculnya China adalah pembentukan ARF, untuk melibatkan China dan Myanmar dalam pengaturan keamanan di kawasan Asia Pasifik. Dan pembentukan Asia Tenggara yang lebih terintegrasi, dengan pembangunan AFTA pada permulaan 1990an, sekaligus merupakan tanggapan atas persaingan modal global yang melimpah. Kepentingan ASEAN dalam keuntungan ekonomi ini juga memotivasi pelibatan Myanmar dalam pengembangan integrasi ekonomi. ${ }^{15}$

Malaysia, Indonesia dan Singapuralah yang membantu Myanmar mendapatkan tempat di dalam ASEAN. Sebagai investor terbesar di Myanmar, dukungan Singapura bagi keanggotaan ASEAN tidak didasarkan atas masalah-masalah hak azasi manusia. Singapura tidak secara terbuka menentang perlakuan Myanmar atas lawan-lawan politiknya. Negara ini lebih prihatin dengan ekonomi Myanmar dan khususnya kebijakan-kebijakannya tentang investasi asing. "Melalui dukungannya atas kepentingan Mynmar di ASEAN, Singapura berharap dapat mempengaruhi pemikiran ekonomi para pemimpin militer Myanmar dan mendapatkan akses yang lebih besar ke sumber daya alam dan pasar senjatanya. Singapura sudah lama merupakan salah satu pensuplai senjata utama bagi Myanmar."16

\footnotetext{
${ }^{14}$ Ibid., h. 40

${ }^{15}$ Ibid., h. 41

${ }^{16}$ Ibid., h. 43
} 
Bagi Aung Saw, pertimbanganpertimbangan geopolitiklah yang mendorong ASEAN menerima Myanmar menjadi anggota ASEAN. Di samping kegusaran bahwa menolak keanggotaan Myanmar berarti suatu undangan bagi China untuk berperan lebih besar di negara itu, pengutukan dunia Barat atas rejim Myanmar dan terutama sanksi-sanksi yang diberlakukan atasnya oleh Amerika Serikat dilihat oleh beberapa pihak sebagai suatu upaya untuk memaksakan nilai-nilai asing atas ASEAN.

At a time when the supposed superiority of "Asian values" was still a favourite theme of Asian leaders eager to argue that the region's increasing prosperity was deeply rooted in their countries' cultures, any attempt by the West to take the moral high ground was met with resentment and derision. For some Asian leaders, particularly Prime Minister Mahathir Mohammad of Malaysia, but to a lesser extent even others with more liberal views, admitting Burma was a way for ASEAN to indicate their rejection of Western condescension. ${ }^{17}$

Sejak 1997 terjadi perubahanperubahan besar di dalam ASEAN. Sementara sebagian besar pemimpin ASEAN masih berpegang pada kebijakan non-interference, Thailand dan Filipina mulai melakukan perubahan atas kebijakan constructive engagement pada Myanmar.

Pada 1998, Dr. Surin Pitsuwan, menteri luar negeri Thailand, memperkenalkan konsep "flexible engagement" sebagai alternatif bagi constructive engagement. Ia menolak anggapan bahwa negara-negara anggota ASEAN tidak berhak untuk saling mengeritik kebijakan dalam negeri

${ }^{17}$ Ibid., h. 44 negara anggota lain apabila kebijakan itu berdampak atas negara anggota lain. Surin menunjuk kepada arus pengungsi Myanmar ke Thailand sebagai contoh intervensi Myanmar. Ia mengatakan kepada menteri-menteri luar negeri negara anggota ASEAN lainnya: "We do not seek to interfere in the internal affairs of any country but we will voice our opinion on any issues that impact our country's ability and our people's well-being." Ia juga mendesak Myanmar untuk mencari penyelesaian konflik politik dalam negeri melalui dialog. Ia melanjutkan: "We are convinced that only through dialogue will there be a national reconciliation that will bring about a stable and prosperous Myanmar."18 Kendatipun inisiatif kedua negara anggota ASEAN tidak mengakibatkan suatu perubahan mendasar dalam pemikiran tentang hubungan antar-negara ASEAN, harus diakui bahwa pernyataan Surin Pitsuwan itu berakibat dalam penggeseran sikap ASEAN tentang campur tangan dalam negeri.

Selama 1999-2000, sebelum Thaksin Shinawatra memegang kekuasaan, perjuangan rakyat Myanmar menuju demokrasi dan masyarakat yang terbuka mencapai puncaknya dengan bantuan masyarakat internasional. ASEAN jauh lebih bersatu dalam menekan Myanmar membuka masyarakatnya, dan menteri luar negeri Surin Pitsuwan mendorong ASEAN untuk meningkatkan dialog dengan Myanmar.

Sejak Thaksin berkuasa mulai permulaan 2001, kebijakan Thailand terhadap Myanmar diputarbalikkan. Setelah beberapa minggu ketegangan di perbatasan dan sikap tegas terhadap peranan Myanmar dalam perdagangan obat-obat terlarang lintas batas, Thaksin tanpa diduga memperlunak

${ }^{18}$ Ibid., h. 46 
kebijakannya terhadap Myanmar.

Sejak waktu itu, tulis Kavi Chongkittavorn,

Thailand's credibility on Burma disappeared. ... Thailand failed miserably to assert itself in the ASEAN overall approaches albeit it was the most affected by the Burmese growing oppression. Bangkok's willingness to play second fiddle to Burma further divided ASEAN and stymied broader cooperation with international community. ${ }^{19}$

Bagi Kavi Chongkittavorn, perilaku Perdana Menteri Samak Sundravej adalah yang paling memalukan: ia memuji pemimpinpemimpin Myanmar sebagai tokohtokoh yang cinta damai. Di bawah pemerintah Surayud Chulanont (20067), kebijakan Thailand ialah tidak membuat hubungan-hubungan baru atau perbaikan atas hubunganhubungan yang sudah ada. Myanmar dapat membuat transisi ke demokrasi apabila pemerintah-pemerintah Thailand yang berkuasa di tahun-tahun itu tidak membuat masalah Myanmar suatu masalah bilateral.

The leader's personal and group interests linked to Burma weakened not only Thai credibility, it also belittled Bangkok's voice within ASEAN. That helps explain why in the absence of a Thai role, Singapore, Malaysia and Indonesia have become more pro-active in shaping the grouping's views and positions on Burma.

Ketika Perdana Menteri Abhisit Vejjajiva dan Menteri Luar Negeri Kasit berkuasa mereka menghadapi masalah yang berat. "They have to revitalise and synergise the role of Thailand, ASEAN and the international community to

${ }^{19}$ Kavi Chongkittavorn, "Understanding new Thai policy towards Burma", Regional Perspective, The Nation, 5 Januari 2009 move the situation in Burma forward." 20 Thailand harus membuat suatu strategi yang komprehensif untuk menghadapi Myanmar yang mencakup berbagai kepentingan ASEAN. Masalah Myanmar bukanlah lagi merupakan masalah Thailand, bahkan sudah merupakan masalah yang lebih luas dari ASEAN.

... After all, the Burmese quagmire is not the problem of any particular country or regional community. It must be kept at the multilateral level so that all stakeholders can work together to end the current impasse and sufferings. ${ }^{21}$

Masalah Myanmar sudah bukan lagi hanya merupakan masalah perbatasan antara Thailand dan Myanmar lagi, melainkan sudah dibuat lebih luas oleh Thailand sendiri, sudah mencakup ASEAN, bahkan seluruh dunia, karena sudah dibuat lebih berkisar pada demokrasi dan hak azasi manusia, bukan lagi masalah perbatasan. Penekanan atas hak azasi manusia, demokrasi dan bahkan peran dan permintaan Aung San Suu Kyi, faktor-faktor pendorong di belakang kebijakan Amerika Serikat, sudah menjadi patokan pula bagi Thailand untuk menyelesaikan permasalahannya dengan Myanmar.

Thailand hendak menyelesaikan masalah perbatasan dengan Myanmar dalam kerangka yang lebih luas. Melalui perjuangan demokrasi dan pengakuan hak azasi manusia Thailand berusaha untuk dapat menyelesaikan masalahmasalah bilateral setelah pendekatanpendekatan untuk menghadapi masalah perbatasan antar kedua negara dan arus pengungsi yang tiada hentinya, dengan mengembangkan constructive engagement dan flexible response, tidak berhasil. Pada 1998 Menteri Luar Negeri Ali Alatas

\footnotetext{
${ }^{20}$ Ibid.

${ }^{21}$ Ibid.
} 
memperkenalkan konsep "enhanced interaction" untuk mencari jalan ke luar: konsep ini mencakup pemberian tekanan atau pesan yang bersahabat apabila masalah dalam negeri suatu negara anggota mempunyai dampak yang mengganggu kehidupan negaranegara ASEAN lainnya. Tetapi pendekatan inipun tidak banyak bermanfaat.

\section{Masalah Pendekatan melalui Mekanisme Penyelesaian Konflik ASEAN}

Thailand memang tidak pernah mengajukan pendekatan ASEAN untuk mencoba mencari penyelesaian atas konflik perbatasannya dengan Myanmar. Lain halnya dengan sengketa antara Kamboja dan Thailand tentang candi Preah Vihear di perbatasan antara kedua negara itu. Thailand meminta bantuan Indonesia untuk menengahi dan membantu menyelesaikan konflik dengan Kamboja itu.

Apabila konflik perbatasan yang terjadi antara Thailand dan Kamboja segera diusahakan penyelesaiannya melalui pelibatan pihak ketiga, Indonesia, mengapa, kita bertanya kembali, persengketaan perbatasan antara Thailand dan Myanmar tidak diusahakan kedua belah pihak melalui pihak ketiga dalam ASEAN?

Konsultasi dan dialog memang ditentukan sebagai cara untuk mengusahakan penyelesaian damai dalam Piagam ASEAN, Bab VIII, Settlement of Disputes, Pasal 22, General Principles, ayat 1 dan 2 .

Lebih tegas adalah ketentuan dalam Treaty of Amity and Cooperation in Southeast Asia, yang mendasari penyelesaian sengketa dalam Piagam ASEAN. Dalam Pasal 13, Bab IV ditetapkan "In case disputes on matters directly affecting them should arise, especially disputes likely to disturb regional peace and harmony, they shall refrain from the threat or use of force and shall at all times settle such disputes among themselves through friendly negotiations".

Apabila penyelesaian suatu persengketaan hendak dilakukan melalui proses regional ASEAN, maka para negara anggota ("High Contracting Parties") membentuk, "sebagai badan yang berkelanjutan", suatu Dewan Tinggi ("High Council"), yang terdiri dari seorang wakil setingkat menteri dari setiap negara anggota untuk mencatat "keberadaan suatu sengketa atau keadaan" yang "dapat mengganggu perdamaian dan harmoni regional". Mereka harus mengikuti upaya penyelesaian persengketaan antara pihak-pihak yang bertikai, maka Dewan Tinggi akan mencatat pertikaian atau keadaan dan akan merekomendasikan kepada para pihak yang bertikai cara-cara penyelesaian yang pantas ("appropriate means of settlement") seperti "good offices, mediation, inquiry or conciliation". Dewan Tinggi itu sendiri dapat pula memfungsikan diri sebagai suatu komite "mediation, inquiry or conciliation". Dan apabila dianggap perlu, maka Dewan Tinggi akan merekomendasikan tindakan-tindakan yang tepat untuk mencegah "pemburukan perselisihan atau keadaan" ("deterioration of the dispute or the situation" (Pasal 14 dan 15).

Ketentuan-ketentuan di atas hanya dapat diberlakukan apabila pihak-pihak yang bertikai setuju bahwa ketentuan-ketentuan itu dapat diberlakukan atas pertikaian mereka. Tetapi hal ini tidak berarti bahwa para negara anggota lainnya yang tidak terlibat dalam pertikaian itu tidak boleh menawarkan berbagai bantuan untuk menyelesaikan pertikaian itu. Dan pihak-pihak yang bertikai harus dapat menerima tawaran bantuan itu. (Pasal 
16) Ketentuan-ketentuan dalam Traktat ini tidak menutup kemungkinan untuk menggunakan cara-cara penyelesaian damai suatu pertikaian sebagaimana tercantum dalam Pasal 33(1) Piagam Perserikatan Bangsa-Bangsa, yang berarti pelibatan International Court of Justice sebagai badan PBB dalam penyelesaian suatu pertikaian antarnegara. Negara-negara anggota ASEAN yang terlibat dalam pertikaian harus didorong untuk mengambil inisiatif guna menyelesaiakan pertikaian mereka melalui negosiasi yang bersahabat sebelum "resorting to the other procedures provided for in the Charter of the United Nations" (Pasal 17).

Treaty of Amity and Cooperation in Southeast Asia belum pernah diterapkan dalam menyelesaikan persengketaan perbatasan di ASEAN. Ada sebab yang menonjol untuk hal ini, yang terlihat jelas dari persengketaan antara Indonesia dan Malaysia tentang pulaupulau Ligitan dan Sipadan.

Sejak semula memang Malaysia bermaksud membawa sengketa Sipadan dan Ligitan ke Mahkamah Internasional dan tidak mencari penyelesaian melalui mekanisme penyelesaian sengketa ASEAN. Alasan Malaysia sangat jelas seperti diuraikan menteri luar negeri Malaysia pada waktu itu, Ahmad Badawi. Keenganan Malaysia untuk meyelesaikan persengketaan tentang kedua pulau itu lebih disebabkan oleh kedudukan Malaysia yang mempunyai persengketaan perbatasan dengan negara-negara ASEAN lainnya, dengan delapan dari sepuluh negara anggota ASEAN:

Perdana Menteri [Dr. Mahathir] sudah mengatakan, isu yang berkaitan dengan tuntutan begini ini bagi Malaysia adalah isu yang sudah melibaskan Malaysia dengan negara-negara ASEAN lain. Kita ada masalah yang berkaitan dengan garis batas itu dengan Brunei, dengan Filipina, Thailand, dengan Singapura ... Jadi dalam posisi seperti ini, lebih baik kita bawa ke pihak ketiga yang tidak ada masalah ... Dan alhamdulillah, Bapak Presiden Soeharto amat memahami masalah Malaysia. Karena itu diambil pihak ketiga yang paling netral, dan itu ialah ICJ. Dan oleh sebab itu kedua pemimpin telah setuju untuk merujukkan masalah ini ke ICJ. Oleh karena itu kedua pihak akan meningkatkan prosedur yang akan sama-sama. ${ }^{22}$

Memang, Mochtar Kusumaatmadja, mantan menteri luar negeri Indonesia, bersikeras supaya perselisihan yang terjadi antar negara anggota ASEAN sebaiknya diselesaikan melalui AHC (ASEAN High Council). "Sebaiknya persoalan itu tetap dibawa ke AHC yang jelas dibentuk anggota ASEAN. Kalau anggota ASEAN tidak mengakui integritas lembaga yang dibentuk sendiri, lantas siapa yang mau mengakui? Dalam hal ini, kedua negara harus menerima apa pun keputusan AHC," tandas Mochtar Kusumaatmadja. Tetapi Malaysia tetap keberatan. Setelah Malaysia menolak penyelesaian melalui AHC, Indonesia tidak mengusulkannya lagi. ${ }^{23}$

Ada sebab lain, mungkin yang lebih utama, dalam penyelesaian persengketaan perbatasan melalui mekanisme ASEAN. Sebab ini tercantum di dalam Treaty of Amity and Cooperation itu sendiri. Pasal 2 dari Traktat Persahabatan dan Kerjasama menegaskan bahwa negara-negara pihak harus berpegang pada prinsipprinsip berikut, yaitu:

a. Saling menghormati "independence", kedaulatan, persamaan, integritas teritorial dan identitas nasional semua bangsa;

\footnotetext{
${ }^{22}$ lbid.

${ }^{23}$ Kompas, 14 Agustus 1996
} 
b. Hak setiap Negara untuk menjalankan eksistensi nasionalnya bebas dari campur tangan dari luar, subversi atau pemaksaan;

c. Tidak campur tangan dalam masalah dalam negeri masing-masing negara anggota;

d. Penolakan ancaman dengan atau penggunaan kekerasan;

Dengan demikian, "settlement of differences or disputes by peaceful means" dan "effective cooperation among themselves" tidak mudah diberlakukan bagi penyelesaian bersama persengketaan antarnegara anggota. Penegasan "tidak campur tangan" dalam masalah dalam negeri masing-masing negara anggota dikhawatirkan justru akan membenarkan campur tangan itu. Hal ini lebih-lebih mengkhawatirkan ketika Surin Pitsuwan berargumentasi bahwa konsep "flexible engagement" berarti bahwa negara-negara anggota ASEAN berhak untuk saling mengeritik kebijakan negara anggota lain apabila kebijakan itu berdampak, baik positif, maun negatif, atas negara anggota lain. Konsep "enhanced interaction" yang diperkenalkan Ali Alatas pun dapat diartikan demikian: pemberian tekanan atau pesan yang bersahabat apabila masalah dalam negeri suatu negara anggota mempunyai dampak yang mengganggu kehidupan negara-negara ASEAN lainnya. Penggunaan konsepkonsep ini, yang dianggap melakukan" pelanggaran" atas pengertian kedaulatan dan tidak campur tangan dalam kebijakankebijakan negara-negara anggota lain untuk menyelesaikan suatu ketegangan atau perselisihan sebagaimana tercantum dalam TAC akan tetap menyulitkan penyelesaian damai persengketaan perbatasan melalui mekanisme ASEAN, yang memang lebih politis sifatnya daripada hukum.

Penyelesaian perselisihan teritorial atau perbatasan akan tetap tegas antar pemerintah sifatnya, kendatipun itu berarti membawa permasalahan ini ke badan hukum internasional seperti International Court of Justice. ASEAN sudah harus berfikir bagaimana perselisihan teritorial dan perbatasan antarnegara anggota diselesaikan dengan menggunakan mekanisme penyelesaian perselisihannya sendiri. Seperti kata Mochtar Kusumaatmadja di tahun 1996: "Kalau anggota ASEAN tidak mengakui integritas lembaga yang dibentuk sendiri, lantas siapa yang mau mengakui?"

\section{Masalah Sengketa Preah Vihear}

Dalam persengketaan tentang wilayah di sekitar Candi Preah Vihear, Kamboja menegaskan bahwa daerah yang dipersengketakan merupakan wilayah kedaulatannya yang sudah diputuskanInternational Court of Justice (ICJ - Peradilan Internasional) di tahun 1962.

In its 9:3 verdict, ${ }^{24}$ the ICJ ruled that Cambodia's map, drawn up by French surveyors during 1904-07, put the temple area in Cambodiaand Thailand (Siam, until 1939) had not shown discernible objections previously.

Peta pembuatan Perancis ini kemudian menjadi sumber persengketaan karena ia "memanipulasi pembatasan geografis yang alami". Thailand tidak menyetujui peta itu karena ia bertentangan dengan persetujuan antara Prancis dan Siam pada 1904. Peta itu menentukan demarkasi sepanjang "watershed line" yang memisahkan kedua negara. Suatu "watershed line" adalah sebutan bagi suatu daerah perbukitan atau punggung bukit yang memisahkan air yang

\footnotetext{
${ }^{24}$ Keputusan ICJ, yang terdiri dari 9 suara yang mendukung dan 3 suara yang menentang, kedaulatan Kamboja atas Preah Vihear pada 1962
} 
mengalir ke berbagai sungai, lembah atau laut. Di sini "watershed line" mengikuti jajaran gunung Dângrêk. ${ }^{25}$ (lihat Gambar 1).

Pembuatan peta Prancis itu dilakukan kurang lebih sepuluh tahun setelah Siam menyerahkan sebagian besar wilayah barat Kamboja sekarang kepada Prancis. Itu terjadi ketika Prancis berkuasa di Indocina dan ketika Siam dipaksa untuk menandatangani sejumlah perjanjian dengan negaranegara penjajah dari Eropa. Siam melakukan hal itu untuk mempertahankan kemerdekaannya. ${ }^{26}$ Tetapi, Thailand di Peradilan Internasional di Den Haag, tidak mempersoalkan pemetaan wilayah yang dipersengketakan, melainkan mempersoalkan apakah Peradilan Internasional mempunyai jurisdiksi atas masalah perbatasan ini. Pemerintah Thailand berpendapat bahwa deklarasi Siam sebelumnya yang mengakui yurisdiksi Permanent Court of International Justice sudah tidak berlaku lagi dengan pembubaran badan itu di tahun 1946. Thailand lalu berkesimpulan bahwa Peradilan Internasional tidak mempunyai jurisdiksi lagi atas masalah perbatasan antara Thailand dan Kamboja karena Thailand tidak pernah mengakui yurisdiksi pengganti Permanent Court of International Justice.

Di bulan Mei 1961, CGI menolak keberatan awal pemerintah Thailand dan menetapkan bahwa Peradilan

\footnotetext{
${ }^{25}$ Boundaries:A Briefing Note on the Cambodian-Thai Border Tensions, July 2011, Cambodian Center for Human Rights,

http://www.cchrcambodia.org/admin/media/analysis/an alysis/english/Blurred\%20Boundaries\%20\%20A\%20Briefing\%20Note\%20on\%20the\%20Cambodia n-Thai\%20Border\%20Tensions.pdfensions

26 Thitinan Pongsudhirak, Chulalongkorn University, "Domestic determinants of the Thai-Cambodian dispute", East Asia Forum, May 18th, 2011, http://www.eastasiaforum.org/2011/05/18/domesticdeterminants-of-the-thai-cambodian-dispute/
}

Internasional mempunyai kompetensi dalam masalah perbatasan antara kedua negara ini. Setahun kemudian, ICJ, dengan suara 9 melawan 3 menguatkan kedaulatan Kamboja atas Candi Preah Vihear.

Dalam menjelaskan keputusan ini, presiden ICJ berpendapat bahwa pemerintah Thailand, yang sebelumnya telah menerima syarat-syarat konvensi 1904, tidak dapat sekarang mengingkari bahwa negara itu tidak pernah menyetujui perjanjian itu. Dengan kata lain, pemerintah Thailand tidak dapat mengklaim dan menikmati keuntungan dari penyelesaian dan kemudian mengatakan bahwa negara itu tidak pernah terikat pada perjanjian itu. Dalam mendukung keputusannya, ICJ bahwa pemerintah Thailand sesudah 1904 terus menggunakan dan bahkan menerbitkan peta-peta yang menunjukkan bahwa Preah Vihear terletak di Kamboja. (International Courtof Justice, 1962b).27

Wakil Thailand selanjutnya mengungkapkan bahwa yurisdiksi CGI atas sengketa perbatasan ini, apabila itu ada, hanya dapat berlaku dengan persetujuan pemerintah Thailand, dan persetujuan itu tidak dapat ditarik dari pengajuan masalah perbatasan oleh pemerintah Kamboja. Sebagai akibat, pemerintah Thailand meminta supaya CGI mengumumkan bahwa badan itu tidak mempunyai jurisdiksi atas masalah kedaulatan Preah Vihear yang diajukan pemerintah Kamboja kepada CGI. (International Court of Justice, 1962a:133-152)

Dalam menjelaskan keputusan ini, presiden ICJ berpendapat bahwa pemerintah Thailand, yang sebelumnya telah menerima syarat-syarat konvensi

\footnotetext{
${ }^{27}$ Ronald Bruce St John, Preah Vihear and the Cambodia-Thailand Borderland, http://www.dur.ac.uk/resources/ibru/publications/full/b sb1-4 john.pdf, 8 Agustus 2011
} 
Gambar 1. Preah Vihear Ceded to France and the Current Thai-Cambodian Boundary

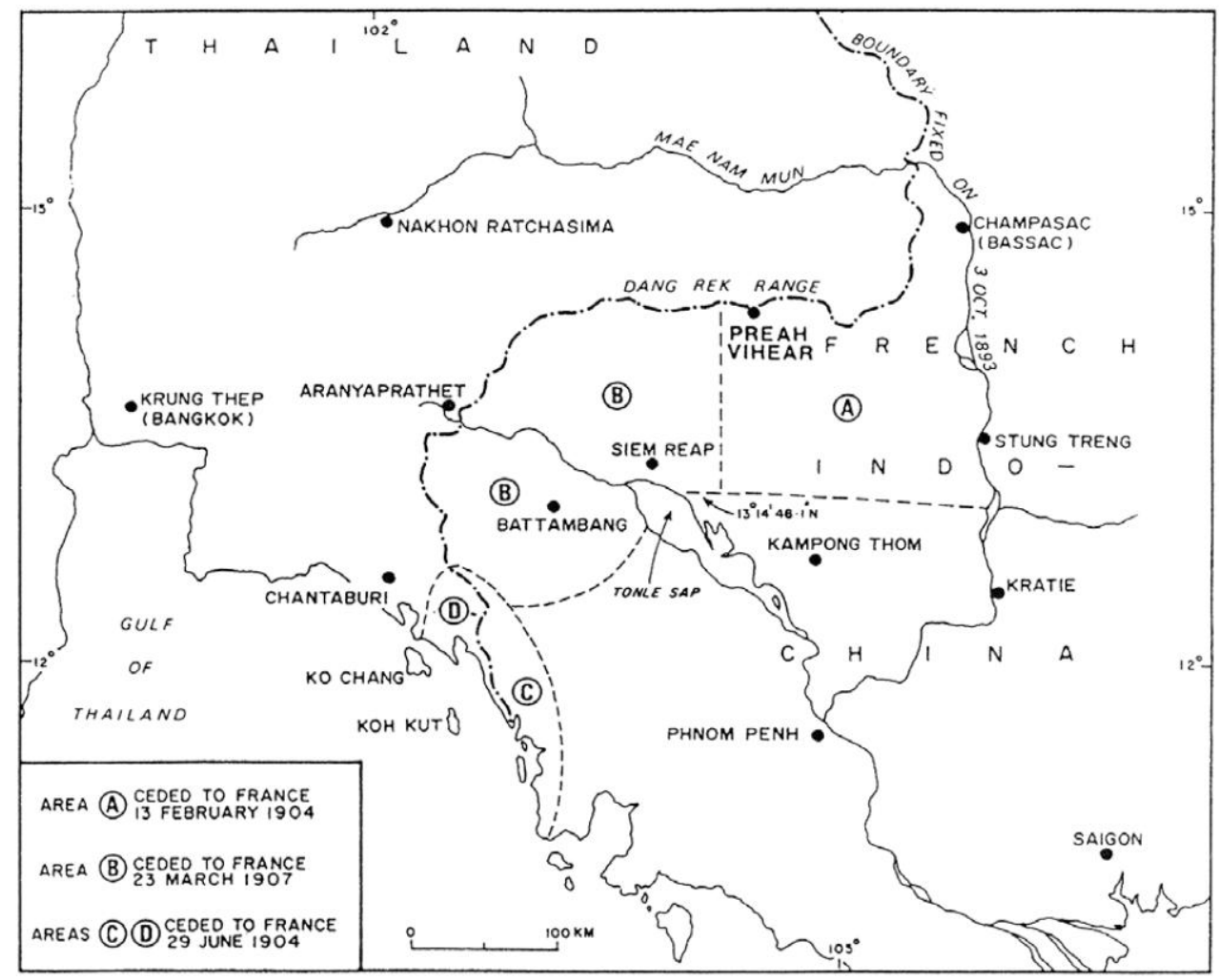

Sumber: Ronald Bruce St John, Preah Vihear and the Cambodia-Thailand Borderland, http://www.dur.ac.uk/resources/ibru/publications/full/bsb1-4_john.pdf, diunduh 8 Agustus 2011.

1904, tidak dapat sekarang mengingkari bahwa negara itu tidak pernah menyetujui perjanjian itu. Dengan kata lain, pemerintah Thailand tidak dapat mengklaim dan menikmati keuntungan dari penyelesaian dan kemudian mengatakan bahwa negara itu tidak pernah terikat pada perjanjian itu. Dalam mendukung keputusannya, ICJ menunjukkan bahwa pemerintah Thailand sesudah 1904 terus menggunakan dan bahkan menerbitkan peta-peta yang menunjukkan bahwa Preah Vihear terletak di Kamboja. (International Courtof Justice, 1962b). ${ }^{28}$

\footnotetext{
${ }^{28}$ Ronald Bruce St John, Preah Vihear and the Cambodia-Thailand Borderland, http://www.dur.ac.uk/resources/ibru/publications/full/b sb1-4 john.pdf, 8 Agustus 2011
}

\section{Tanggapan Kamboja dan Thailand atas Keputusan Peradilan Internasional}

Kamboja memperhatikan seruan Dewan Keamanan PBB untuk menghentikan sengketa perbatasan. Negara ini juga segera menerima terms of reference bagi penempatan peninjau Indonesia yang tidak bersenjata untuk mengawasi gencatan senjata sepanjang perbatasan Preah Vihear serta siap untuk menghadiri pertemuan yang disarankan ASEAN. Selanjutnya, atas keputusan Peradilan Internasional di Den Haag Perdana Menteri Hun Sen menyatakan bahwa pemerintahnya tidak akan menarik tentaranya dari zone demiliterisasi sampai Thailand setuju dengan suatu "timetable". Tetapi ia menolak mengadakan pembicaraan 
tentang "timetable" dengan Thailand. Dan Hun Sen menghendaki bahwa Indonesia harus duduk di meja perundingan yang sama supaya perundingan mencapai hasil akhir yang dapat diandalkan. Sebaliknya, Thailand setuju dengan keputusan Peradilan Internasional. Tetapi ada beberapa hal yang harus diselesaikan di dalam negeri sebelum tindakan yang nyata bisa diambil.

\section{Masalah Dalam Negeri Thailand Berkaitan dengan Candi Preah Vihear}

Penjabat Perdana Menteri Abhisit Vejjajiva menyatakan bahwa penarikan mundur tentara dari daerah sengketa harus dirundingkan di dalam General Border Committee (GBC). Hal ini dengan jelas menandakan bahwa Thailand hanya mau melakukan penarikan tentara kedua belah pihak dari daerah perbatasan sebagai suatu keputusan bilateral, bukan trilateral, artinya tanpa Indonesia di meja perundingan. "Thailand wants only two parties to be involved. Cambodia wants at least three." 29

Thailand yang tetap tidak dapat menerima keterlibatan pihak ketiga dalam sengketa Preah Vihear belum menjawab pertemuan yang disarankan dengan alasan bahwa mereka harus terlebih dahulu membahas terms of reference.

Sikap ini merupakan tekanan dari kelompok nasionalis "baju kuning", Aliansi Rakyat untuk Demokrasi (PAD), yang mengajukan surat protes kepada Duta Besar Republik Indonesia di Bangkok atas misi peninjau Indonesia untuk perbatasan Thailand-Kamboja. Surat PAD menyatakan bahwa terms of reference Indonesia berarti "a foreign military operation to control Thai military operation defending Thai

${ }^{29}$ Suthichai Yoon, "Demilitarised Zone versus depoliticised approach", The Nation, 28 Juli 2011 sovereignty which has been deliberately violated by Cambodia." Karena itu, peninjau Indonesia yang direncanakan untuk ditempatkan di daerah perbatasan yang dipersengketakan tidak sesuai dengan pengaturan bilateral Thailand-Kamboja untuk menyelesaikan sengketa perbatasan.

Sejak Janurari 2011, PAD telah memrotes pemerintah Thailand atas "soft pedaling" masalah perbatasan dan juga meminta pemerintah Thailand untuk menghapus "memory of understanding" antara Thailand dan Kamboja sejak Juni 2000 sebagai suatu kerangka bagi penyelesaian sengketa perbatasan antara kedua negara, menarik diri dari Unesco World Heritage Committee dan memaksa penduduk Kamboja keluar dari daerah yang menurut kelompok ini merupakan milik Thailand. 30

\section{Kendatipun Duta Besar}

Thailand, Virachai Plasal, dalam pernyataannya di Peradilan International (1 Juni 2011) menegaskan sesuai dengan kaidah diplomatik, bahwa politik dalam negeri Thailand tidak ada sangkut pautnya dengan masalah sengketa Preah Vihear, seperti dinyatakan Kamboja di depan sidang itu $^{31}$, pembahasan tentang sikap Thailand atas permasalahan Candi Preah Vihear memperlihatkan bahwa sikap Thailand ini merupakan pencerminan dari pertentangan politik dalam negeri Thailand. Dr Pavin Chachavalpongpun, misalnya, dalam analisanya tentang sengketa Candi Preah Vihear (dalam suatu seminar

\footnotetext{
30 Pou Sothiarak, "Preah Vihear Dispute Put ASEAN's Effectiveness to Test", Viewpoints, http://web1.iseas.edu.sg/?p=2958, diunduh 26 Agustus 2011

${ }^{31}$ Ambassador Virachai Plasai dalam Closing Statement on the Temple case at ICJ, 1 Juni 2011, Bangkok Post, 2 Juni 2011,h. 9: "Sixth, Thailand's domestic politics has nothing to do with the issue before us today as claimed by Cambodia's counsel. Thailand is a functioning democracy with a parliamentary system. ..."
} 
yang diadakan Institute of Southeast Asian Studies, Singapura tentang ASEAN dan konflik Thailand-Kamboja, 24 Februari 2011) menunjuk kepada "krisis domestik" di Thailand dan bagaimana krisis itu berdampak atas hubungan Thailand dan Kamboja. Ia menyebutnya "linkage politics", kaitan antara Preah Vihear dan perkembangan dalam politik dalam negeri Thailand.

Suatu 'pertarungan' berkembang di Thailand antara aktor negara dan non-negara, antara baju Kuning (royalists Yellow Shirts) dan baju Merah. Partai yang melambangkan baju kuning, People's Alliance for Democracy (PAD), merupakan kekuatan pendorong yang besar dalam politisasi sengketa Preah Vihear. Politisasi itu terdiri dari "unseat the Thaksin-backed regime of Samak Sundaravej" di tahun 2008 sampai dengan "stirring up of Thai nationalism" melalui "fabricating historical memories", seperti "lost territory". Bahkan politisasi itu menjurus kepada "deligitimasi" pemerintah Abhisit. ${ }^{32 " K i t a}$ menghendaki pemerintah yang baru yang akan melindungi wilayah dan tanah air kita", kata juru bicara PAD, Panthep Wongpuaphan.33 "I think we are still suffering from the ultranationalist sentiments which have been propagated by Thai governments since World War II,"kata Charvit Kasetsin, seorang sejarawan Thailand. "Expansionism became more popular in modern-day Thailand under its later military dictators." 34

\footnotetext{
${ }^{32}$ ISEAS Executive Summary Seminar on "ASEAN and Thai-Cambodian Conflict from Historical,Current and Regional Perspectives", 24 February 2011, http://web1.iseas.edu.sg/?p=2663, diunduh 7 Agustus 2011

${ }^{33}$ Peter Janssen and Robert CarmichaelDPA, ANALYSIS: Domestic politics muddy Thai-Cambodian border spat, 9 Februari 2011, http://kimedia.blogspot.com/2011/02/analysis-domesticpolitics-muddy-thai.html ${ }^{34}$ Ibid.
}

Pada tingkat yang lebih dalam, sengketa Candi Preah Vihear menunjukkan betapa parah politik dalam negeri Thailand. Pavin langsung menuding angkatan bersenjata Thailand sebagai dalang utama permusuhan dengan Kamboja. Bentrokan antara kedua belah pihak telah memberikan kesempatan bagi angkatan bersenjata Thailand untuk "mengambil alih sepenuhnya politik luar negeri", untuk menghadapi apa yang dipersepsikan mereka sebagai musuh utama negara itu. Angkatan Darat Thailand bergelut kuat dengan pemerintah Abhisit Vejjajiva dan Kementerian Luar Negeri untuk menguasai kebijakan luar negeri Thailand atas Kamboja. Bagi tentara, mengambil alih kebijakan luar negeri atas Kamboja sangat penting karena hal ini menjamin peran politik dan wibawa mereka dalam proses pengambilan keputusan atas pengelolaan ketegangan dengan Kamboja.

The military has wanted to be in charge of the Thai-Cambodian conflict, and it is willing to belittle the role of the government and the foreign ministry in this process.

Percekcokan tentang intervensi Indonesia dalam konflik ThailandKamboja, tentang peran ASEAN dalam penyelesaian konflik itu (Thailand lebih menekankan modalitas penyelesaian bilateral) tidak lain adalah perilaku militer yang putus asa atas tanda-tanda kehilangan kendalinya sebagai pemegang kekuasaan politik Thailand akhir-akhir ini. "Perhaps the Thai military may want to learn some new facts."

"Secara bilateral, Kamboja tidak lagi bersikap pasif", kata Pavin. Negara itu sudah menolak dipermainkan terus oleh tetangganya yang "lebih maju, lebih modern dan lebih unggul."Sebaliknya, di dalam negeri Thailand sendiri sikap anti-militer 
dengan cepat meningkat:

The rejection of the election result and the coup will no longer be responded lightly by many prodemocracy Thais. 35

Pavin menyarankan bahwa penyelesaian masalah ini di Thailand hanya mungkin apabila nasionalisme tidak "disalahgunakan", sejarah tidak "didistorsi", bahwa permasalahan Preah Vihear perlu "didepolitisasi", dan hubungan "people-to-people" di dalam Thailand sendiri harus diperkuat. ${ }^{36}$

Bagi Michael Vatikiotis, masalah Preah Vihear dimunculkan kembali di Thailand sebagai bagian dari persengketaan yang makin mendalam antara kekuatan yang pro dan kontra Perdana Menteri Thaksin Shinawatra. Dengan persengketaan ini kemauan baik yang masih ada di antara keduanya "which have a long history of mutual dislike and suspicion", menguap menjelang akhir 2009 setelah Kamboja menuduh Thailand melanggar janji dan memunculkan masalah Preah Vihear di forum-forum multilateral.

Sebaliknya, Thailand merasa dikhianati setelah Perdana Menteri Hun Sen menunjuk Thaksin Shinawatra sebagai salah seorang penasehat ekonominya, yang menjurus ke arah ketegangan diplomasi yang tinggi dan penarikan duta besar masing-masing negara.

A deep sense of recrimination and bitterness now prevails; Cambodia has accused Thailand of espionage amid leaked Thai official documents that talk of preparations for war. Thailand accuses Cambodia of harbouring fugitives from Thai law and acting as a sanctuary for those

\footnotetext{
${ }^{35}$ Pavin Chachavalpongpun, The Disputed ThaiCambodia Border, Ceri Science-Po, http://www.cerisciencespo.com/archive/2011/mai/art pc.pdf, diunduh 26 Juli 2011

${ }^{36} \mathrm{lbid}$.
}

who plot violent demonstrations aimed at bringing down the government. ${ }^{37}$

Apalagi, Hun Sen memuji Thaksin sebagai "teman yang sangat baik" dan korban dari "a politically compromised judicial system". Thailand menganggap tawaran itu sebagai campur tangan dalam politik dalam negerinya dan segera menurunkan derajat hubungan diplomatiknya dengan Kamboja. ${ }^{38}$

Lalu ada masalah transisi politik Thailand sesudah pemilihan umum 3 Juli 2011. Kendatipun Hun Sen akan berhadapan dengan pemerintah Thai yang baru yang dipimpin oleh Yingluck Shinawatra, adik perempuan Thaksin Shinawatra, hal itu tidak berarti bahwa hubungan antara kedua negara itu dengan sendirinya akan membaik. "Politik dalam negeri Thailand umumnya lebih rumit dari apa yang diperkirakan banyak orang."

Lagi pula,

if things should look brighter for Phnom Penh and Bangkok with the installation of a new government, the parliamentary process and constitutional "interpretation" of the world court's order under the new regime could see road blocks spring up along the way.

Pemerintah Thailand yang baru, di bawah Perdana Menteri Yingluck Shinatwatra dengan Pheu Thai Party (PTP) berhasil memperbaiki hubungan bilateral dengan Kamboja. Saluran komunikasi dan negosiasi dibuka kembali, kendatipun ketidaksetujuan

\footnotetext{
${ }^{37}$ Thailand and Cambodia: Time for ASEAN to Act. Posted by Michael Vatikiotis, February 25, 2010, MacArthur Foundation, Asia Security Initiative Blog, http://asiasecurity.macfound.org/blog, diunduh 7 Agustus 2011

${ }^{38}$ Craig Guthrie, "Cambodia rattles Thailand's chain", Asia Times Online, 10 November 2009, http://www.atimes.com/atimes/Southeast Asia/KK10Ae $\underline{01 . h t m l}$
} 
tentang keputusan ICJ 1962 atas Preah Vihear sebagai wilayah Kamboja berlanjut. Apabila keputusan ICJ yang baru, yang sedang ditunggu di pertengahan 2013 ini, kembali menguntungkan Kamboja, maka PM Yingluck harus menghadapi seranganserangan nasionalisme luas terhadap kebijakannya.

\section{Peran Indonesia dalam Upaya Penyelesaian Masalah Preah Vihear}

Kavi Chongkittavorn, wartawan harian The Nation, Bangkok, pada 2 Agustus 2010 menulis: Ketika sengketa antara Kamboja dan Thailand tentang wilayah di sekitar candi Preah Vihear merebak di perbatasan antara kedua negara itu, Thailand meminta bantuan Indonesia untuk menengahi dan membantu menyelesaikan konflik itu. Permintaan bantuan itu bahkan mencakup pengurusan kepentingan Thailand di Kamboja apabila sampai kedutaan Thailand ditutup untuk sementara waktu. Di sela-sela pertemuan APEC yang diadakan di Singapura di bulan November 2009, PM Thailand, Abhisit Vejjajiva, menjelaskan tentang konflik di antara kedua negara itu kepada Presiden Susilo Bambang Yudhoyono. Thailand memberikan kepercayaan penuh kepada Indonesia untuk mencari jalan untuk menurunkan ketegangan di antara kedua negara itu. ${ }^{39}$

Dalam pernyataannya di Hotel Marina Mandarin Singapura (16 November 2009) setelah mengikuti sidang-sidang APEC, Presiden Yudhoyono menyatakan bahwa dalam pendapatnya "masih ada kesempatan bagi Thailand dan Kamboja untuk menyelesaikan masalah perbatasan mereka secara bilateral". Dan menteri luar negeri Indonesia akan berhubungan terus dengan rekan-

\footnotetext{
${ }^{39}$ C.P.F. Luhulima, Bab V, Usaha Penyelesaian Konflik Perbatasan Myanmar-Thailand: Jalur ASEAN
}

rekannya sesama menteri luar negeri tentang masalah perbatasan ini.

Indonesia akan tunggu bagaimana perkembangan yang terjadi di antara Thailand dan Kamboja dengan harapan bahwa mereka akan mendapatkan jalan yang terbaik untuk mengatasi sengketa mereka. Dan apabila dalam perembukan mereka, mereka setuju ada sesuatu yang positif yang dapat disumbangkan negaranegara ASEAN, "maka kita pasti melakukan hal itu."

Yudhoyono menambahkan bahwa dalam pertemuan-pertemuannya dengan mereka, ia menyarankan agar kedua negara anggota ASEAN itu menyelesaikan masalah perbatasan mereka secara bilateral. Baginya, "lebih baik kedua pemimpin negara yang bersengketa mencoba menyelesaikan masalah perbatasan mereka secara bilateral, "tanpa membawanya ke forum ASEAN atau membuatnya suatu masalah internasional, karena itu tidak baik bagi ASEAN secara keseluruhan" ${ }^{40}$

Sebelumnya, pada 16 Oktober 2008, Yudhoyono sudah memberikan pandangannya tentang konflik antara kedua negara ini: "Yang paling baik keduanya harus bisa menahan diri, melanjutkan perundingan," pesan Yudhoyono. Maka itu, lanjutnya, Indonesia terus mendorong agar tidak terjadi konflik terbuka.

"Penyelesaiannya harus dengan semangat kekeluargaan yang baik, dengan semangat ASEAN Security Community." 41

Kemudian, ketika konflik terbuka kembali pecah antara kedua negara pada Februari 2011, Presiden Yudhoyono langsung menyatakan bahwa Indonesia, sebagai Ketua ASEAN, "memiliki tanggungjawab

\footnotetext{
${ }^{40}$ http://preahvihear.com/?p=1401, diunduh 7 July 2011

${ }^{41}$ Viva News, 16 Oktober 2008
} 
moral untuk ikut menjadi bagian dari solusi konflik antara Thailand dan Kamboja". Atas dasar itulah ia mengutus menteri luar negeri Marty Natalegawa ke kedua negara yang bersengketa untuk bertemu dengan rekan-rekannya, "dan sudah ada komunikasi sebelumnya mengapa Menteri Luar Negeri Indonesia mengambil inisiatif bertemu dengan kedua counterpart-nya," Sudah dua kali, kata Yudhoyono, ia sendiri mengadakan pertemuan terpisah dengan perdana menteri Thailand dan Kamboja untuk membahas sengketa perbatasan di antara kedua negara dan mendesak supaya konflik itu jangan sampai meluas. Dan keduanya sudah berjanji untuk lebih menahan diri. "Sebagai chairman dari ASEAN, saya menyerukan untuk benar-benar menahan diri dan segala permasalahan bisa dicarikan solusinya secara damai, sesuai dengan Piagam ASEAN yang harus sama-sama kita junjung tinggi."42

$$
\text { Pada waktu pertemuan- }
$$
pertemuan itu kedua pihak berjanji untuk menahan diri, sehingga tidak terjadi insiden di daerah perbatasan mereka. Yudhono berharap bahwa tugas yang diberikan kepada menteri luar negeri akan dapat menemukan cara penyelesaian sengketa perbatasan itu sesuai dengan Piagam ASEAN. ${ }^{43}$

Sebelum pernyataan Presiden Yudhoyono pada 8 Februari itu, Sekretaris Jenderal ASEAN juga sudah mendorong kedua belah pihak untuk mendapatkan penyelesaian sengketa mereka secara damai. "Saya sangat prihatin dengan situasi yang gawat di perbatasan antara Thailand dan Kamboja. Konflik yang sengit ini harus

\footnotetext{
${ }^{42}$ Konflik Thailand-Kamboja, Indonesia Menyerukan Solusi Damai dalam Semangat ASEAN, 7 Februari 2011, http://www.presidenri.go.id/index.php/fokus/2011/02/0 7/6446.html

${ }^{43}$ Antara, 8 Februari 2011
}

dikendalikan dan piahk-pihak yang bertikai hrus sesegera mungkin kembali ke meja perundingan." Surin Pitsuwan sudah bertemu dengan Wakil Perdana Menteri dan Menteri Luar Negeri Hor Namhong dan Menteri Luar Negeri Thailand, Kasit Piromnya, dan ia telah meminta mereka berdua untuk tenang, saling mengendalikan diri dan supaya mereka kembali ke meja perundingan secepat mungkin.

Sekretaris Jenderal ASEAN Surin Pitsuwan, selanjutnya meminta Thailand dan Kamboja untuk menerima tawaran bantuan ASEAN untuk menemukan gencatan senjata sementara guna mengurangi ketegangan di antara keduanya demi kepentingan yang lebih besar bagi kedua negara itu sendiri dan ASEAN secara keseluruhan. Peningkatan permusuhan antara Thailand dan Kamboja dapat menurunkan kepercayaan kepada ASEAN dan dapat mempengaruhi pariwisata, investasi dan peningkatan ekonomi. ${ }^{4}$

Saran penyelesaian sengketa yang dikemukakan Yudhoyono memang sesuai dengan Pasal 13 Treaty of Amity and Cooperation in Southeast Asia (TAC). Pasal 13 TAC menyatakan: "The High Contracting Parties shall have the determination and good faith to prevent disputes from arising".

Tetapi apabila sengketa di antara mereka terjadi, terutama sengketa yang dapat mengganggu perdamaian dan harmoni regional,

They shall refrain from the threat or use of force and shall at all times settle such disputes among themselves through friendly negotiations. (Penekanan dari penulis)

Karena itu, setelah persengketaan terjadi di antara kedua negara anggota ASEAN sejak 2008,

${ }^{44}$ lbid. 
Yudhoyono mengatakan bahwa kedua belah pihak segera kembali ke meja perundingan dan menghindari peningkatan lanjut sengketa itu. Sengketa antara Thailand dan Kamboja ini tidak sampai pembentukan High Council, yang sesuai Pasal 6 mempunyai yurisdiksi untuk menyelesaikan sengketa di antara negara anggota ASEAN.

Imbauan dan inisiatif Yudhoyono dan negara ASEAN lainnya tidak banyak membawa hasil. Pada 14 Februari 2011, Kamboja mengajukan masalah Candi Preah Vihear kepada PBB. Sesudah sidang tertutup PBB itu, kedua negara yang bersengketa menegaskan bahwa mereka mendambakan perdamaian dan menghendaki penyelesaian diplomatik.

Untuk pertama kali Dewan Keamanan PBB membuat keputusan yang belum pernah dibuatnya dengan meminta ASEAN untuk menjamin dialog yang efektif antara kedua anggotanya dalam upaya penyelesaian sengketa perbatasan antara keduanya. Kata Sekretaris Jenderal ASEAN, Dr. Surin Pitsuwan

“UNSC's open and official support for conciliation efforts to the ASEAN Chair is a sign that the United Nations has faith in ASEAN to help its Member States find amicable regional solutions to bilateral problems such as this." 45

Sesudah sidang tertutup DK PBB itu, Marty Natalegawa menyatakan bahwa ASEAN sendiri masih mencoba untuk "extract from the two countries concerned at the highest level possible a clear commitment that they wish to solve the problem peacefully through dialogue and negotiation." Marty juga

\footnotetext{
${ }^{45}$ Historic Firsts: ASEAN Efforts on Cambodian-Thai Conflict Endorsed by UNSC, Official Website of the Association of Southeast Asian Nations, 21 Februari 2011, http://www.aseansec.org/25924.htm
}

mengatakan bahwa ASEAN mencoba mencari suatu mekanisme atau sistem komunikasi yang lebih dapat diandalkan untuk menjamin bahwa gencatan senjata dapat bertahan dan suatu "road map" untuk solusi diplomatik dapat dirumuskan. Tetapi Marty tetap menegaskan bahwa penyelesaian akhir harus datang dari negosiasi di antara Thailand dan Kamboja itu sendiri. Pernyataan pers Dewan Keamanan PBB "called on the two sides to display maximum restraint and avoid any action that may aggravate the situation." Anggotaanggota Dewan Keamanan juga mendesak kedua negara melaksanakan gencatan senjata secara permanen dan "resolve the situation peacefully and through effective dialogue." 46

Tetapi ASEAN ternyata tidak dapat meredakan perselisihan ini. Kedua belah pihak semula setuju mengizinkan Indonesia memantau persengketaan. Tetapi Thailand kemudian menarik kembali keputusannya ketika militer mengklaim bahwa pemantau dari luar, sekalipun dari ASEAN, menggerogoti kedaulatan negara.

Kemudian, pada 28 April 2011, Kamboja secara resmi mendaftarkan interpretasi ulang dari keputusan ICJ tentang Candi Preah Vihear pada 15 Juni 1962, melampaui upaya ASEAN. Salah satu fungsi utama ICJ ialah menyelesaikan sengketa hukum yang diajukan negara anggotanya. Kamboja juga meminta ICJ membuat aturan sementara untuk melarang kegiatan militer Thailand di wilayah perbatasan dekat Candi Preah Vihear, yang berarti menarik semua pasukan Thailand dari wilayah sekitar Preah Vihear.

\footnotetext{
${ }^{46}$ Edith M. Lederer, UN Urges Peaceful Thai-Cambodia Settlement, The Irrawady, 15 Februari 2011, http://www.irrawaddy.org/article.php?art id=20757 diunduh 7 Agustus 2011
} 
Permintaan yang diajukan Kamboja kepada ICJ itu berbunyi: Karena Candi Preah Vihear terletak di dalam wilayah kedaulatan dan kekuasaan Kamboja, maka pemerintah Kamboja meminta kepada Peradilan Internasional di Den Haag untuk menarik "any military or police forces, or other guards or keepers, stationed by her at the Temple, or in its vicinity on Cambodian territory"sebagai konsekuensi dari pengakuan integritas wilayah Kamboja, "that territory having been delimited in the area of the Temple and its vicinity by the line on the Annex I map, on which the Judgment of the Court is based". ${ }^{47}$

Permasalahan di peradilan ialah apakah Kamboja atau Thailand mempunyai "kedaulatan teritorial" atas wilayah Candi Preah Vihear (lihat Gambar 2). Dalam mementukan masalah ini, peradilan menerapkan "doctrines of acquiescence and estoppel"48 dan dengan tegas memberikan efek legal kepada suatu peta yang pada pembuatannya tidak mengikat sama sekali.

While maps do not, of themselves, conclusively determine a territorial boundary, they may be determinant evidence of the location of a boundary if the map has been integrated as part of a treaty between the relevant states. It was the acceptance or acquiescence by Thailand of the map delineating the boundary that rendered it a part of the treaty itself and thereby bound both states.The Court, on the basis of the doctrine of estoppel, also decided Thailand was precluded from denying the legality of the

\footnotetext{
${ }^{47}$ Request for Interpretation of the Judgement of 15 June 1962 in the Case concerning the Temple of Preah Vihear. Request for the Indication of Provisional Measures, International Court of Justice, 18 Juli 2011, Para 5

48 "Estoppel" menunjuk kepada suatu rangkaian doktrin legal dan adil yang tidak memungkinkan suatu negara menyatakan sesuatu yang berlawanan dengan yang sudah ditentukan secara hukum sebagai kebenaran.
}

map fifty years later - irrespective of its possible incorrectness. Because this map placed the temple in Cambodian territory, the court held that the Temple of Preah Vihear was situated in territory under the sovereignty of Cambodia and that Thailand was obligated to withdraw any military or police forcesstationed at the Temple or in its vicinity on Cambodian territory. ${ }^{49}$

Kamboja meminta Peradilan Internasional untuk mengumumkan tindakan sementara sambil menunggu keputusannya atas permintaan negara itu yang terdiri dari tiga butir, yaitu pertama, penarikan segera dan tanpa syarat dari semua kekuatan militer Thailand dari bagian-bagian wilayah Kamboja yang terletak di sekitar Candi Preah Vihear; ke dua, larangan atas semua kegiatan militer di wilayah Candi Preah Vihear, dan ke tiga, supaya Thailand menahan diri dari setiap tindakan yang dapat "interfere" dengan hak teritorial Kamboja atau "the rights of Cambodia or aggravate the dispute in the principal proceedings", dan supaya pengumuman tindakan sementara itu dilakukan segera. ${ }^{50}$ Tidak satupun dari ketiga tindakan yang diajukan Kamboja ke Peradian Internasional menyebut peran ASEAN dalam menengahi konflik ini.

Sambil menunggu keputusan tentang interpretasi ulang keputusan 15 Juni 1962, Peradilan Internasional memutuskan (dengan sebelas suara melawan lima), bahwa kedua belah pihak segera menarik pasukan mereka dari "provisional demilitarized zone" dan "refrain from any military presence

\footnotetext{
${ }^{49}$ Tamara Lam-Plattes, The Temple Torn Between Two Nations: A Legal and Political Analysis of the On-Going Conflict Over the Preah Vihear Temple on the Cambodian-Thai Border, University of San Francisco School of Law, 2010,

www.usfca.edu/law/docs/templetorn/ 18 Juni 2013

${ }^{50}$ Ibid., Para 11
} 


\section{Gambar 2. Sketch-Map of Provisional Demilitarized Zone Identified by The Court}

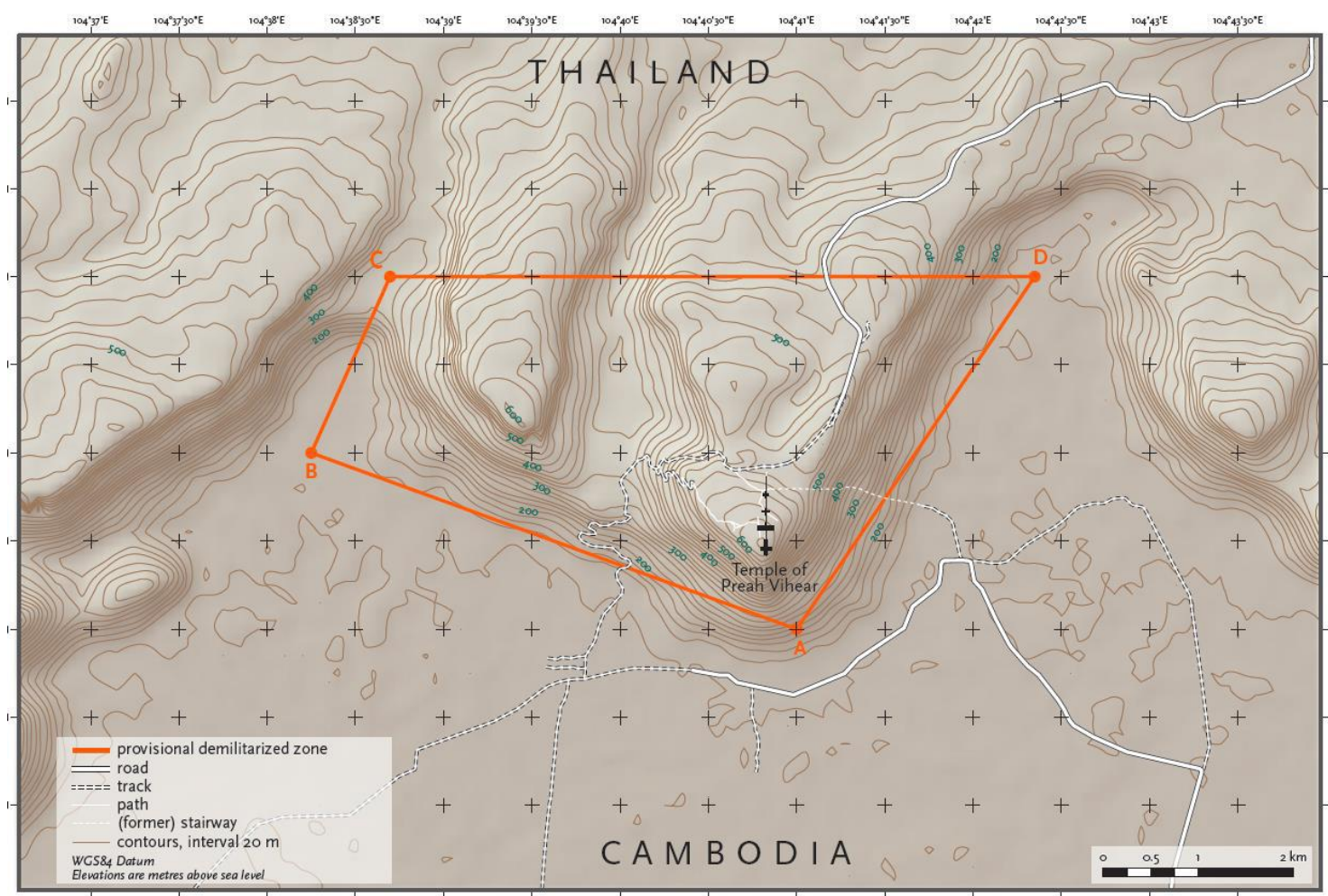

Sumber: ICJ, Request for Interpretation of the Judgement of 15 June 1962 in the Case concerning the Temple of Preah Vihear. Request for the Indication of Provisional Measures, International Court of Justice, 18 Juli 2011

within that zone and from any armed activity directed at that zone". Paragraf 62 dan 63 dari keputusan ICJ berbunyi:

62. Whereas this provisional demilitarized zone shall be delimited by straight lines connecting the following points, the co-ordinates of which are calculated on the basis of the WGS 84 system: point $\mathrm{A}$, situated at latitude $14^{\circ} 23^{\prime}$ $\mathrm{N}$ and longitude $104^{\circ} 41^{\prime} \mathrm{E}$; point $\mathrm{B}$, situated at latitude $14^{\circ} 24^{\prime} \mathrm{N}$ and longitude $104^{\circ} 38^{\prime} 15^{\prime \prime} \mathrm{E}$; point $\mathrm{C}$, situated at latitude $14^{\circ} 25^{\prime} \mathrm{N}$ and longitude $104^{\circ} 38^{\prime} 40^{\prime \prime} \mathrm{E}$; and point $\mathrm{D}$, situated at latitude $14^{\circ} 25^{\prime} \mathrm{N}$ and longitude $104^{\circ} 42^{\prime} 20^{\prime \prime} \mathrm{E}$ (see sketchmap [Gambar 2])

63. Whereas both Parties, in order to comply with this Order, shall withdraw all military personnel currently present in the zone as thus defined; whereas both Parties shall refrain not only from any military presence within that provisional demilitarized zone, but also from any armed activity directed at the said zone.

Bagi ASEAN, keputusan yang paling penting dari ICJ ialah kedua belah pihak "harus melanjutkan kerjasama yang sudah dilakukan di dalam ASEAN, dan, khususnya membolehkan peninjau dari organisasi itu 'to have access to the provisional demilitarized zone'". 51 Keputusan ini disetujui dengan limabelas suara (satu suara menentang). Selama itu, "both parties shall refrain from any action which might aggravate or extend the dispute before the Court or make it more difficult to resolve". Paradilan Internasional juga menetapkan bahwa

${ }^{51}$ lbid., Decision 3 
setiap Pihak harus memberitahu Peradilan tentang "compliance with the above provisional measures". 52

Keputusan Peradilan Internasional membanggakan ASEAN, khususnya Presiden Indonesia. Dengan bangga Yudhoyono menyatakan: "Kita telah mendapatkan pengakuan masyarakat internasional sebagai organisasi regional karena kita telah dapat, secara efektif, menghadapi masalah keamanan kita sendiri." 53

Keputusan sementara Peradilan Internasional ini harus dilaksanakan kedua belah pihak supaya ASEAN dapat menempatkan peninjaunya di wilayah itu dan menjaga berlakunya gencatan senjata sehingga Peradilan Internasional dapat mengambil keputusannya.

Akhirnya, pada 11 November 2013 Mahkamah Internasional di Den Haag memutuskan bahwa Candi Preah Vihear dan wilayah sekitarnya adalah milik Kamboja seperti dinyatakan di bawah ini:

The Court therefore concludes that the first operative paragraph of the 1962 Judgment determined that Cambodia had sovereignty over the whole territory of the promontory of Preah Vihear, as defined in paragraph 98 of the present Judgment, and that, in consequence, the second operative paragraph required Thailand to withdraw from that territory the Thai military or police forces, or other guards or keepers, that were stationed there. ${ }^{54}$

\footnotetext{
52 Ibid., Decision 4

${ }^{53}$ Mustaqim Adamrah, "Yudhoyono boasts RI's success in chairing ASEAN", The Jakarta Post, 9 Agustus 2011

${ }^{54}$ Para 107, Request For Interpretation Of The Judgment Of 15 June 1962 In The Case Concerning The Temple Of
}

Perdana Menteri Thailand, Yingluck Shinawatra, mengatakan kepada rakyat Thailand bahwa kedua negara akan bekerja sama untuk mencapai dan melanggengkan perdamaian antara kedua bangsa. Semoga sikap PM Yingluck itu didukung semua unsur dalam masyarakat Thailand. Demikian pula halnya dengan Perdana Menteri Hun Sen yang berjanji akan bekerja sama dengan Thailand untuk menjaga perdamaian di perbatasan dan tidak akan memicu ketegangan di perbatasan.

\section{Thailand - Malaysia}

Pemberontakan di selatan tidak akan berakhir sampai penguasa Thailand mulai memahami keluhan sejati orang-orang Muslim-Melayu di wilayah itu. 55

Sumber konflik adalah keluhan politik - suatu hasrat untuk merubah sistem. ${ }^{56}$ (Captain Soonpuen Somapee)

Bagi Captain Somapee,seorang perwira angkatan laut Thailand, "Konflik Siam-Patani bersumber pada tiga pertimbangan: 1) kehendak kerajaan Patani untuk berdaulat; 2) konsolidasi Kerajaan Siam di tahun 1909; dan 3) ancaman yang dirasakan atas identitas Muslim Melayu dari kebijakan asimilasi Thailand." 57 Inti konflik antara dua kekuatan ini ialah Patani ingin bebas dari kekuasaan Siam sedangkan Siam ingin mempertahankannya sebagai suatu bagian darinya. Tetapi setelah Siam menguasai Patani dan menyerapnya ke

\footnotetext{
Preah Vihear (Cambodia V. Thailand).

55 "Repeating the same old mantra in the deep South," Editorial, The Nation of Bangkok, dimuat di The Jakarta Post, 13 Mei 2012

${ }^{56}$ Captain Soonpuen Somapee, Insurgency In Southern Thailand And The Four-Track Mitigation Policy, http://www.navy.mi.th/navedu/acd/data docu/capt soo npuen somapee/southern thailand.pdf ${ }^{57}$ Ibid.
} 
dalam Kerajaan Siam bersama Kedah, Kelantan, dan Trengganu di 1785, kerusuhan di Patani tidak juga berhenti.

Inggris kemudian memaksa Siam untuk menyerahkan Kelantan, Perak, Kedah dan Perlis, tetapi mengakui kedaulatan Thailand atas Patani dalam suatu traktat perbatasan pada 1909.58 Raja Rama V lalu menggantikan semua sultan dan menunjuk pejabat-pejabat Thailand untuk memerintah wilayah ini.

Sejak waktu itulah orang-orang Melayu Muslim di selatan Thailand, kecuali di Satun, mulai memberontak melawan kekuasaan Thailand. Kebijakan asimilasi Thailand mengancam identitas orang Melayu. Pemerintah Siam mulai mendidik orang-orang Melayu Islam membaca dan menulis dalam bahasa Thai di bawah Undang-Undang Pendidikan Dasar tahun 1921. Tetapi, bagi orang Melayu keMelayuannya identik dengan Islam - keduanya tidak dapat dipisahkan. Di sinilah terletak masalah inti kekuasaan Thailand di wilayah Selatan ini. Dengan memaksa mereka belajar bahasa Thai, orang-orang Melayu merasa bahwa pemerintah Thailand mencoba untuk memisahkan

\footnotetext{
${ }^{58}$ The Burney Treaty, so named after Henry Burney, head emissary from the East India Company, and known in Siamese history as the Treaty of Amity and Commerce (Siam-UK), was concluded with King Rama III in the latter part of 1826. This followed Dr. John Crawfurd's 1822 mission to the court of King Rama II, the principle objective of which was to determine Siam's position on the Malay states. The treaty acknowledged Siamese claims over the four northern Malay states of Kedah, Kelantan, Perlis and Terengganu. The treaty further guaranteed British possession of Penang and their rights to trade in Kelantan and Terengganu without Siamese interference. The four Malay states were not represented in the treaty negotiation. In 1909, the parties of the agreement signed a new treaty that superseded the 1826 treaty. The 1909 treaty, known as Anglo-Siamese Treaty of 1909, also known as the Bangkok Treaty of 1909, transferred the four Malay states from Siamese to British dominion.(http://en.wikipedia.org/wiki/Burney Treaty, June 2013)
}

agama dari etnisitas Melayu mereka. Masalahnya menjadi lebih berat ketika pemerintah Phibun (1938-1944) menyebarluaskan nasionalitas Thai. Semua orang di Thailand, termasuk Melayu Islam, diharuskan berbahasa Thai dan mengenakan pakaian Thai.

Orang-orang Muslim-Melayu atau Melayu-Muslim melihat integrasi nasional sebagai integrasi budaya Melayu ke dalam budaya Thai. Bagi mereka Budisme Thai dan Islam Melayu "berasal dari dua orientasi kosmologis yang berbeda".

Mereka tidak mau diintegrasikan ke dalam negara Thai. Mereka tidak mau kehilangan otonomi agama dan budaya mereka. Apabila negara merupakan manifestasi dari kosmologi Buddha, orang-orang Muslim Melayu tidak mau merupakan bagian dari padanya.

Orientasi etnis dari kedua komunitas, Budhisme Thai dan Islam Melayu, dikategorikan sebagai "sistem yang tertutup". "Muslim Melayu ini memisahkan diri dari orang luar (bahkan orang Muslim lain) kecuali apabila mereka merupakan anggota kelompok yang sama atau berbahasa Melayu pula." Dengan demikian, berpindah ke agama Islam tidaklah cukup. Seseorang harus "masuk Melayu" pula untuk dapat diterima sebagai seorang Muslim di wilayah ini. "Proses ini diperkuat melalui kesetiaan kepada memori historis dan peran para ulama dan 'tok gurus', yang menegaskan dan mempertahankan identitas etnis-religius masyarakat Muslim Melayu."59

Dengan pemisahan Kelantan, Trengganu dan Kedah utara dari pusat

\footnotetext{
${ }^{59}$ Imtiyaz Yusuf, "The Southern Thailand Conflict and the Muslim World," http://www.bangkokbiznews.com/2006/special/south/p df/southern01.pdf , h. 12
} 
keilmuan Islam, Patani, yang berada di wilayah Thailand, maka warisan dari demarkasi ini ialah meluasnya jejaring lintas-batas dengan banyak orang di kedua pihak memegang dua kewarganegaraan. Banyak orang Muslim yang hidup di Thailand Selatan mempunyai kartu identitas Malaysia dan terdaftar sebagai pemilih dalam pemilihan umum di Kelantan, Malaysia. Keadaan ini tidak dapat diatasi Thailand dan harus pula diperhatikan Malaysia sebelum negara ini mengambil tindakan. 60

Perbatasan antara kedua negara ini tidak pernah merupakan hambatan bagi kegiatan lintas batas. Dwikewarganegaraan merupakan jalur mereka untuk mencari kerja dan mendapatkan kesempatan sosial lainnya. Malaysia tidak mengakui dwikewarganegaraan, tetapi sudah merupakan rahasia umum bahwa kepemilikan dwikewarganegaraan itu makin meluas. Secara tradisional Thailand membolehkannya, tetapi akhir-alkhir ini pemerintah mencoba menariknya dari warganegaranya di sebelah Selatan. Tidak ada konsensus tentang berapa orang yang mempunyai dwikewarganegaran itu. Tetapi penduduk tanpa dwikewarganegaraan juga dapat melintasi batas dengan surat lintas batas yang berlaku untuk enam bulan. Kendatipun demikian, banyak pula orang yang tidak perdulikan surat lintas batas itu. Di bulan Agustus 2004 kedua negara setuju untuk mengganti pas perbatasan dengan "smart cards" yang akan diperkenalkan di kedua negara, tetapi bilamana tanda pengenal

\footnotetext{
${ }^{60}$ Rita Camilleri, “Muslim Insurgency in Thailand and The Philippines: Implications for Malaysia's Cross-Border Diplomacy,"

http://www.une.edu.au/asiacentre/PDF/No27.pdf, h. 70
}

elektronik itu akan diberlakukan masih belum jelas. ${ }^{61}$

Kedua negara ini mempunyai sejarah yang panjang tentang pertikaian di perbatasan "but have consistently resolved them in original and innovative ways".62 Respons Malaysia atas keadaan ini ialah bekerjasama dalam berbagai proyek pembangunan di Thailand Selatan. Malaysia memang menghadapi dilema di perbatasannya dengan Thailand: bagaimana mendukung minoritas Muslim di negara lain tanpa mengusik kedaulatan negara lain itu. Kendala ini diperbesar karena Malaysia merupakan anggota ASEAN. Tetapi pada lain pihak, sebagai anggota Organisasi Konferensi Islam Malaysia diharapkan merespons secara positif atas kepentingan orang-orang Muslim. Dilema ini yang dihadapi Malaysia pula. Sebagai anggota ASEAN, Malaysia harus berpegang kepada sikap tidak campur tangan dalam permasalahan dalam negeri negara anggota lain dan harus mengakui kedaulatan Thailand atas wilayah Patani, karena perbatasan antara kedua negara itu sudah ditetapkan dan diterima oleh kedua belah pihak. Tetapi keanggotaan pada OIC mengharuskannya membantu kebutuhan orang Muslim di seberang perbatasannya dengan Thailand. Dan Thailand sendiri adalah "observer" pada OIC itu. Suatu dilema yang menarik.

Untuk mencoba mengatasi masalah bersama ini, suatu sidang kabinet bersama antara Malaysia dan Thailand diadakan pada Desember 2002. Kedua belah pihak setuju untuk

\footnotetext{
${ }^{61}$ John Funston, Thailand's Southern Fires: The Malaysian Factor, http://www.une.edu.au/asiacentre/PDF/No26.pdf, h. 3-4

${ }^{62}$ Captain Somapee, Insurgency In Southern Thailand And The Four-Track Mitigation Policy,http://www.navy.mi.th/navedu/acd/data docu/ca pt soonpuen somapee/southern thailand.pdf, h. 69
} 
meningkatkan perang terhadap teror dan penyelundupan lintas-batas (termasuk pengakhiran dwinasionalitas), dimulainya pembangunan pipa gas bersama melitasi wilayah Thailand, koordinasi strategi industri, serta meningkatkan pariwisata dan perdagangan. Suatu persetujuan kerjasama militer ditandatangani pada 22 Mei 2003 yang mencakup patroli bersama, standarisasi prosedur operasi militer dan membuka pintu-pintu masuk untuk meningkatkan kegiatan ekonomi di antara keduanya. Di bulan Juli 2003 Mahathir dan Thaksin memulai suatu konferensi tingkat tinggi tahunan (dikenal sebagai Annual Consultation) dan setuju bagi "suatu derajat integrasi ke lima propinsi Thailand Selatan dan negara-negara bagian Malaysia utara, Kedah, Perlis dan Kelantan." Rencana ini kemudian dikenal sebagai Joint Development Strategy dan bertujuan untuk melakukan kerjasama di berbagai bidang ekonomi dan sosial di wilayah perbatasan. ${ }^{63}$

Bagi Capt. Somapee,

Malaysia merupakan negara tetangga yang sangat baik. Negara itu mencoba segala sesuatu untuk menghentikan kekerasan di Selatan. ... Orang-orang Thai perlu belajar bagaimana mengakhiri masalah di selatan dari orang-orang lain dan pemerintah Thai perlu menjelaskan bagaimana mengakhirinya dengan benar, kalau tidak kekerasan tidak akan pernah berakhir. Masalahnya ialah bagaimana pemerintah Thai menjelaskan kepada elit politiknya bahwa hanya perundingan merupakan cara mengakhirinya. Sekali mereka mendukung pendekatan ini, maka kita akan melihat keberhasilan." 64

\footnotetext{
${ }^{63}$ John Funston, "Malaysia and Thailand's southern conflict: reconciling security and ethnicity," Contemporary Southeast Asia, August 2010, h. 3

${ }^{64}$ Captain Soonpuen Somapee, dalam surat elektronik ke C.P.F. Luhulima, May 9, 2012
}

Pembahasan selanjutnya akan mengetengahkan faktor Thailand, faktor Malaysia dan peran Dr. Mahathir Muhammad dalam usaha penyelesaian konflik di daerah perbatasan antara kedua negara dan kerangka ASEAN.

\section{Faktor Thailand}

Kesulitan yang terdapat di pihak Thailand ialah bahwa pemerintah tidak mau mengakui secara terbuka bahwa negara itu menghadapi pemberontakan yang berkepanjangan, tidak mau menghentikan

"mentalitas pengingkaran" atas pemberontakan di bagian selatan negara itu.

Kalau saja pemerintah Thai dapat menerima kenyataan bahwa negara ini menghadapi suatu pemberontakan yang menghancurluluhkan, dan bahwa jalan terbaik untuk keluar dari keadaan itu adalah mengakhiri mentalitas pengingkaran dan mengakui keparahan dari konflik itu dan mengakui sifat etnisnasionalismenya - mungkin kita dapat merubah situasinya. Orang-orang Thai berhak mendapatkan sesuatu yang lebih baik. 65

Karena itu, sangatlah tidak menguntungkan bahwa Kementerian Luar Negeri Thailand tidak punya pilihan dan harus melestarikan sindrom pengingkaran ini dalam diplomasi mereka. "It has always been the military and the folks at Government House who have called the shots as to how the conflict should be dealt with domestically and internationally."

Permasalahan yang paling besar yang dihadapi Thailand ialah "policymakers are not committed to the

${ }^{65}$ The Jakarta Post - "OIC visit and state of denial over the South", 20 Mei 2012, dikutip dari surat kabar The Nation, Bangkok 
idea of a peace process because they think they will lose face and political capital."66 Rasa kehilangan muka dan modal politik di sebagian elit politik Thailand inilah yang menyulitkan negara itu menghadapi kenyataan dan mencari penyelesaian pemberontakan di Patani.

Apabila kelompok yang menjalankan "sindrom pengingkaran" ini tidak dikelola dengan baik, maka mereka dapat menciptakan suatu krisis yang berkepanjangan bagi Thailand. Somapee berpendapat bahwa ada dua langkah untuk menangani para "resistors" ini:

(a) the Thai government must identify ways to change their world view through participation and alter their attitudes, values, and behaviors; and (b) if they still resist the policy, some hard decisions must be made: they must be removed from their government positions so as not to obstruct policy implementation. ${ }^{67}$

Perdana Menteri Thaksin Shinawatra berkuasa sejak permulaan pemberontakan sampai ia disingkirkan dalam suatu pengambilalihan kekuasaan di bulan September 2006. Selama pemerintahannya Thaksin justru intensitas meningkatkan pemberontakan dari tingkatnya yang rendah di 2004-2005. Thaksin menuntut hasil segera dari operasi militer dan menggantikan pimpinan Angkatan Darat ke-4 di selatan Thailand dengan 6 komandan di dalam kurun waktu 3 tahun. Sebanyak 60.000 tentara yang ditempatkan untuk menumpas pemberontakan tidak terorganisasi, sangat korup dan saling menjegal satu sama lain agar mendapatkan jatah yang

\footnotetext{
${ }^{66}$ "OIC visit and the state of denial over the South", The Jakarta Post, 20 May 2012

${ }^{67}$ Somapee, p. 39
}

lebih besar dari sumber keuangan yang dikhususkan bagi operasi militer. "Few troops were deployed, and those who were tended to be in static positions, effectively ceding the countryside to the insurgents."

Para pemberontak dapat memperbesar kekuatannya pada 2006 dan 2007 karena sebagian besar dari kegiatan pemerintah di selatan tidak berfungsi, sedangkan para pemberontak berusaha mengembangkan infrastruktur pemerintahan untuk mengimbangi pemerintah Bangkok. ${ }^{68}$

Tiga bentuk kekerasan terjadi secara berturut-turut sejak Thaksin mulai memerintah di tahun 2004: perampokan senjata dan amunisi dari sebuah kamp militer di bulan Januari; peristiwa berdarah di Mesjid Krueseh pada 28 April dan tragedi Tak Bai pada Oktober 25. Thaksin kemudian menjelaskan bahwa ketiga peristiwa ini tidak terjadi lepas satu dari yang lain, melainkan merupakan bagian dari suatu rencana yang lebih besar yang direncakan oleh suatu jejaring di luar negeri. Pertanyaannya ialah apakah penjelasan yang diberikan Perdana Menteri Thaksin diperoleh dari badan intelijen nasional ataukah menyalahkan pihak luar berarti bahwa kegagalan untuk mendapatkan penyelesaian masalah di Thailand Selatan bukan salah pemerintah Thai saja? "Ultimately, the strategy of blaming an external source proved to be successful beyond the Thai government's wildest expectations when the finger was pointed at two neighboring countries, Malaysia and Indonesia." 69

\footnotetext{
${ }^{68}$ Zachary Abuza, "The Ongoing Insurgency in Southern Thailand: Trends in Violence, Counterinsurgency Operations, and the Impact of National Politics," Institute for National Strategic Studies, Strategic Persepctives 6 , h.3

http://www.ndu.edu/inss/docuploaded/Strategic\%20Per spectives\%206 Abuza\%20.pdf

${ }^{69}$ Ukrist Pathamanand, From Friends to Enemies,
} 
Kemudian, Perdana Menteri Thailand mengejutkan Malaysia dan Indonesia, "bahkan seluruh dunia", ketika ia menyatakan di program radio mingguan yang berjudul "Perdana Menteri Thailand bertemu dengan rakyat" bahwa hutan-hutan di Malaysia "penuh sesak" dengan "pelatihan bersenjata bagi para pemberontak dan bahwa Indonesia merupakan sumber inspirasi gerakan teroris di Thailand." Tidak lama sesudah itu Perdana Menteri Abdullan Badawi mengeluarkan bantahan dan meminta pemerintah Thai membuktikan ucapan itu.

Sesudah bantahan Malaysia
Thaksin tidak lagi mengulangi pernyataannya itu. Tetapi, ia meminta Deputi Menteri Dalam Negeri Thailand Sutham Saengprathun memberikan kesaksian bahwa ia memiliki gambargambar pelatihan militer itu sebagai bukti. Permintaan Thaksin ini kemudian mendeskreditkan Menteri Dalam Negeri yang kemudian menyatakan bahwa ia sendiri belum pernah melihat foto-foto itu. Pemerintah Thailand sendiri tidak pernah memberikan bukti tentang klaim itu kepada Malaysia dan Indonesia.

Thaksin sendiri berperan dalam meningkatkan ketegangan dengan Malaysia dan Indonesia. Ia senantiasa menghindari pembicaraan langsung dengan pihak Malaysia dan Indonesia. Ia bahkan menjuruskan masalah ini "memburuk, dan menjadikannya suatu konflik regional ketika ia mengejutkan rekan-rekan di KTT ASEAN di Vientienne ketika ia mengatakan bahwa ia tidak akan ragu-ragu untuk meninggalkan sidang itu apabila Malaysia atau Indonesia akan mengajukan kekerasan Takbai pada sidang itu. "Hanya dalam satu tahun kita berhasil menjadikan dua teman kita

http://www.thaiworld.org/en/include/print.php?text $=11$ 9\&category id=5\&print=true, 5 Juni 2012 menjadi musuh. Bagaimana mungkin bahwa perseteruan kita dengan Malaysia dan Indonesia dibahas setiap hari di kalangan diplomatik dan disebarkan di berbagai websites dan media lokal dan internasional. Lebih parah lagi, pengabaian pemerintah Thai atas konflik di selatan dan perselisihan dengan pemerintah Malaysia dan Indonesia menginternasionalisasi masalah ini."

Thailand is moving into the structure of the Muslim world - a structure that is diverse in its dimensions and multi-layered in its conflict of power and interest. Inevitably, these are new and sensitive, if extremely perilous, dimensions. The Thai government has thus far not been able to lessen or put an end to the conflict with these two countries. To make matters worse, it has even ignored the negative views expressed by the Muslim world. Since early 2004, the Jakarta Post of Indonesia, the largest Muslim nation in the world, and Saudi Arabia's Arab News have focused their attention on the violence in as well as the Thai government's stance towards the three southern provinces. The problems in Southern Thailand have been represented as a common problem of the Muslim world. ${ }^{70}$

Captain Somapee sangat menyayangkan bahwa pemerintah Thaksin tidak membangun kerjasama yang baik dengan Malaysia. Thaksin menyalahkan Malaysia mendukung para pemberontak di Thailand Selatan. "Malaysia is one of the keys to success in mitigating the insurgency. Thailand needs coordination with Malaysia so that the insurgents cannot use its territory as a safe haven." Sangatlah penting, kata Captain Somapee, bahwa

\footnotetext{
${ }^{70}$ Ukrist Pathamanand, From Friends to Enemies, http://www.thaiworld.org/en/include/print.php?text $=11$ 9\&category id=5\&print=true, 5 Juni 2012
} 
pemerintah Thailand harus bekerjasama dengan pemerintah Malaysia untuk mempercil ruang gerak para pemberontak di wilayah perbatasan sehingga kerjasama ini akan membuat infiltrasi dari Malaysia jauh lebih sulit. ${ }^{71}$

Dibandingkan

dengan

permasalahan perbatasan antara Thailand dengan Myanmar dan Kamboja, masalah perbatasan dengan Thailand - Malaysia sebetulnya merupakan permasalahan di perbatasan bukan masalah perbatasan. Kendatipun demikian penyelesaian di perbatasan di antara kedua negara ini tetap harus diusahakan dalam kerangka ASEAN.

\section{Thailand - Laos}

Sejumlah permasalahan terdapat dalam hubungan Thailand dan Laos. Permasalahan ini mencakup sengketa demarkasi perbatasan yang berkelanjutan (suatu komisi bersama dibentuk setelah konflik bersenjata pada 1980-an), konflik antara kapal-kapal komersial dan kapal partoli perbatasan di sungai Mekong, pemenjaraan warganegara dari masing-masing negara oleh Thailand dan Laos, dan kehadiran pengungsi Laos yang tersisa di tempattempat penampungan di Thailand. Vientienne hanya bersedia menerima para pengungsi yang bersedia kembali atas kemauannya sendiri.

Pada 1893 (dengan kapal perang Prancis mengancam Bangkok) Thailand dengan segan menandatangani traktat Prancis - Siam yang menentukan pengalihan semua wilayah Laos di sebelah timur sungai Mekong ke Prancis. Persetujuan 1904 dan 1907 menambahkan kepada Laos bagian dari provinsi-provinsi Sayaboury dan Champasak di sebelah barat sungai

\footnotetext{
${ }^{71}$ Captain Soonpuen Somapee, Insurgency In Southern Thailand And The Four-Track Mitigation Policy, http://www.navy.mi.th/navedu/acd/data docu/capt soo npuen somapee/southern thailand.pdf, h. 14
}

Mekong.

Auguste Pavie, seorang pegawai negeri dan diplomat Prancis, yang giat memperluas pengendalian Prancis atas Laos pada dua dasawarsa terakhir abad ke sembilanbelas, hendak memperluas Indochina, dan di bulan Desember 1888 tentara Prancis memaksa tentara Siam untuk mengundurkan diri dari Sibsong Chao Thai. Konsul Prancis di Bangkok meminta Siam untuk mengakui Sungai Mekong sebagai batas antara keduanya, dan suatu komisi bersama dikirim untuk melakukan penyelidikan. Di bulan April 1893 menteri luar negeri Siam, Pangeran Thewawong menyarankan untuk membawa persengketaan perbatasan antara keduanya ke arbitrase internasional, tetapi Prancis menolak, bahkan sebaliknya, meminta konsesi dari pemerintah Siam. Prancis lalu mengirim kapal perang Comete ke hilir sungai Chao Phraya untuk memperbesar tekanan mereka. Tetapi pihak Siam memperingatkan Prancis untuk tidak melampaui benteng di Paknam dan meminta bantuan Inggris. Di bulan Mei 1893 pertempuran terjadi di Pulau Khone di sungai Mekong; sejumlah serdadu Vietnam dalam pasukan Prancis terbunuh dan komandannya, Kapten Maurice Thoreux ditawan.

Pada 10 Juli 1893 Pavie memberitahukan Thewawong bahwa ia mengirim kapal-kapal perang Comete dan Inconstant bergabung dengan Lutin untuk melindungi konsulat Prancis, dan setelah pertempuran tiga hari di Paknam mereka menaklukkan tentara Siam. Inggris menawarkan untuk menengahi, tetapi Prancis menolak tawaran itu dan memberikan ultimatum kepada Siam untuk mengundurkan diri dari daerah timur sungai Mekong. Perancis memblokade Bangkok dan pada Juli 29 siap menerima syarat-syarat Prancis. Traktat antara Prancis dan Siam yang ditandatangani di bulan Oktober 
1893 memberikan Prancis tepi timur sungai Mekong sebelah selatan perbatasan dengan China, suatu zona yang didemilitarisasi seluas $25 \mathrm{~km}$ di tepi barat sungai Mekong, status protégé bagi semua orang Vietnam, Laos dan Khmer yang berada di Siam. Selanjutnya Siam harus membayar ganti kerugian yang besar jumlahnya. ${ }^{72}$

Setelah Perancis memberi kemerdekaan kepada Laos pada tahun 1946, Thailand memandang bahwa kesepakatan perbatasan yang ditetapkan sudah tidak berlaku lagi antara Thailand dan Laos. Thailand menuntut wilayah-wilayah yang semula diserahkan ke Perancis pada 1893 itu. Tentu saja hal ini menafikan legalitas kesepakatan historis yang telah dibuat antara Siam dan Perancis saat itu. Memang Perancis tidak menetapkan secara tegas garis batas antara Siam dan Indochina, melainkan hanya wilayah perbatasan saja.

Di tahun 1970an, Vietnam berupaya memperluaskekuasaannyadalam rangka Federasi Komunis Indochina dengan mengirim 70.000 pasukan ke arah barat dan mendekati Thailand. Thailand mencoba menghindari persengketaan yang mungkin akan terjadi di wilayah perbatasannya dengan Laos, sehingga negara itu menawarkan suatu kesepakatan bersama pada tahun 1976 untuk tidak menggunakan kekerasan dalam menyelesaikan masalah perbatasan. Pada tahun 1979, untuk meredam kemungkinan konflik di perbatasan dibentuklah Mekong River Consultative Committee (MRCC). (Lihat Bab 6, hal. 12)

Tetapi sejak 1980 konflik di antara kedua negara, Laos dan Thailand, berlangsung dengan saling

\footnotetext{
72 Sanderson Beck, Siam, Cambodia, and Laos $1800-$ 1950, h. 4. http://www.san.beck.org/20-9Siam,Laos,Cambodia1800-1950.html, 25 Juni 2013
}

penyerangan di antara kedua belah pihak, bahkan dengan melibatkan Perserikatan Bangsa-Bangsa. Ketika pertempuran di antara kedua negara melibatkan angkatan udara di pihak Thailand, Laos mengadukan serangan Thailand kepada Sekretaris PBB, Javier Perez de Cuellar pada 17 Desember 1987 dan kepada Menteri Luar Negeri Zimbabwe Witness Magwende, sebagai ketua Gerakan Non Blok pada 18 Desember 1987.

Pada 28 Desember 1987 Thailand meminta Laos untuk mundur dari daerah sengketa. Dua hari kemudian, 30 Desember 1987, kedua negara yang bersengketa ini sepakat untuk berunding. Sekjen PBB menentukan dan memfasilitasi pertemuan ini pada 4 Januari 1988. Kendatipun demikian, pertempuran di perbatasan tidak berhenti. Pesawat tempur Thailand menyerang tentara Laos di daerah sengketa selama 5 lima hari, 1-5 Februari 1988. Sekjen PBB segera memediasi kembali pada 5 Februari 1988, tetapi Thailand menolaknya. Keduanya kembali bertempur di daerah sengketa selama empat hari, 14-17 Februari 1988. Mungkin karena sudah lelah kedua negara bersepakat untuk menghentikan peperangan pada 17 Februari 1988.

Pada 17 Agustus 1990 kedua negara bersepakat untuk bekerjasama dan menjamin keamanan di daerah perbatasan di antara keduanya. Pada 1112 Maret 1991 kedua negara bersepakat untuk menarik tentara mereka dari daerah perbatasan yang berakhir dengan perjanjian persahabatan dan kerjasama pada 19 Mei 1992 di Bangkok dan persetujuan demarkasi perbatasan pada 19 Mei 1997 dan pada 1 November 1997 penandaan perbatasan dilakukan.

Ketika persengketaan perbatasan antara Laos dan Thailand berlangsung, Laos belum merupakan anggota 
ASEAN. Negara itu menjadi anggota ASEAN pada 23 Juli 1997.

The Lao PDR's accession to Asean on July 23,1997 is the fruit of the implementation of our consistent foreign policy of peace, independence, friendship, and cooperation aimed at contributing to the building of Southeast Asia as a region of peace, stability and cooperation for development. ...Laos' Asean membership is the fruit borne from Laos's foreign policy that contributes to the building of peace, stability and cooperation for development in the region.

Itulah kata-kata Perdana Menteri Laos Thongsing Thammavong, ketika ia memberikan ceramah untuk merayakan ulang tahun ASEAN ke-45 dan ulang tahun ke limabelas bergabungnya Laos dengan ASEAN.73

Persengketaan perbatasan Laos dengan Thailand memang diajukan kepada PBB, tetapi tampaknya penyelesaian sengketa perbatasannya dengan Thailand merupakan kesadaran kedua belah pihak untuk ikut membantu membangun Asia Tenggara sebagai suatu wilayah yang damai, stabil dan bekerjasama untuk melanjutkan pembangunannya, dalam kerangka ASEAN.

\section{Mekanisme Penyelesaian Sengketa ASEAN}

ASEAN dibentuk, seperti dicantumkan dalam Piagam ASEAN, untuk "maintain and enhance peace, security and stability and further strengthen peace-oriented values in the region". (Pasal 1(1)) Untuk dapat melaksanakan tujuan ini, maka ASEAN memerlukan suatu instrumen untuk

73

http://www.vientianetimes.org.la/Video FileVDO/Aug12 Lao mem.htm menyelesaikan sengketa di antara para anggotanya secara damai. Pasal 13 Treaty of Amity and Cooperation (1976) menyatakan bahwa negara-negara anggota ASEAN

shall have the determination and good faith to prevent disputes from arising. In case disputes on matters directly affecting them should arise, especially disputes likely to disturb regional peace and harmony, they shall refrain from the threat or use of force and shall at all times settle such disputes among themselves through friendly negotiations.

Ini adalah langkah pertama untuk mengelola sengketa antara negara anggota menuju penyelesaiannya.

Langkah kedua tercantum di Pasal 14:

To settle disputes through regional processes, the High Contracting Parties shall constitute, as a continuing body, a High Council comprising a Representative at ministerial level from each of the High Contracting Parties to take cognizance of the existence of disputes or situations likely to disturb regional peace and harmony.

Langkah ketiga tercantum di Pasal 15. Apabila tidak terdapat penyelesaian melalui perundingan langsung antar pihak-pihak yang bersengketa, maka :

The High Council shall take cognizance of the dispute or the situation and shall recommend to the parties in dispute appropriate means of settlement such as good offices, mediation, inquiry or conciliation.

High Council dapat juga mengangkat diri sebagai suatu "a committee of mediation, inquiry or conciliation". Dan apabila perlu, maka "High Council shall recommend appropriate measures for the prevention of a deterioration of the dispute or the 
situation".

Tetapi High Council ini hanya dapat melibatkan diri apabila kedua belah pihak yang bertikai setuju badan ini melibatkan diri dalam usaha mencari penyelesaian atas sengketa mereka. Selanjutnya, dan ini tertera dalam Bab 16:

This shall not preclude the other High Contracting Parties not party to the dispute from offering all possible assistance to settle the said dispute. Parties to the dispute should be well disposed towards such offers of assistance.

Jadi, langkah ketiga memungkinkan pula negara-negara anggota yang tidak terlibat dalam pertikaian itu untuk membantu menyelesaikan sengketa yang sedang terjadi. Dan pihak-pihak yang bertikai harus bersikap baik terhadap tawaran bantuan penyelesaian itu.

Langkah keempat (Pasal 17) memungkinkan penggunaan Pasal 33(1) Piagam Perserikatan Bangsa-Bangsa, meskipun mereka tetap dianjurkan untuk melakukan pendekatan bilateral untuk menyelesaikan pertikaian mereka. Memanfaatkan Pasal 33(1) PBB berarti mengajukan sengketa mereka untuk penyelesaian kepada Mahkamah Internasional di Den Haag.

Keempat langkah pendekatan penyelesaian suatu pertikaian wilayah atau perbatasan antara negara anggota ditegaskan kembali dalam Piagam ASEAN. Pada Bab VIII, Settlement of Disputes, Pasal 22(1) tercantum bahwa negara anggota harus berusaha untuk menyelesaikan semua sengketa antar mereka secara damai melalui dialog, konsultasi dan negosiasi, "within an agreed time limit". (Pasal 23(1)). Selanjutnya, pihak-pihak yang bertikai dapat meminta Ketua ASEAN atau Sekretaris Jenderal ASEAN "to provide good offices, conciliation or mediation".
(Pasal 23(2))

Langkah-langkah penyelesaian itu dapat dilihat pada Gambar 3. Upaya penyelesaian sengketa perbatasan di antara anggota ASEAN melalui pembentukan High Council belum berhasil. Keberhasilan itu justru tercapai melalui mekanisme Paradilan Internasional di Den Haag, seperti halnya dengan sengketa LigitanSipadan antara Indonesia dan Malaysia dan sengketa Pedra Branca antara Malaysia dan Singapura. Tetapi sengketa antara Kamboja dan Thailand tentang Candi Preah Vihaer ternyata belum dapat diakhiri oleh Peradilan Den Haag. Peradilan International meminta kedua belah pihak yang bersengketa untuk "melanjutkan kerjasama yang sudah dilakukan dalam ASEAN" dan mengizinkan peninjau ASEAN memasuki zona militer sementara di antara kedua belah pihak.

Pengakuan Peradilan Internasional atas upaya ASEAN untuk meredam sengketa antara kedua belah pihak memperlihatkan bahwa organisasi internasional itu mengakui ASEAN sebagai suatu organisasi regional yang bertujuan meningkatkan kerjasama regional dengan mengatasi konflik antar anggotanya.

Penyelesaian

sengketa perbatasan di antara Thailand dengan negara-negara yang berbatasan dengannya yang belum berhasil di tingkat ASEAN kemungkinan besar disebabkan karena proses penyelesaiannya merupakan proses politik dan bukan proses hukum. Keterlibatan pihak negara dalam setiap upaya penyelesaian berarti bahwa proses itu sarat politik dan tidak memungkinkan penilaian sebab dan kelanjutan sengketa secara objektif. Sudah waktunya ASEAN mempertimbangkan pendekatan hukum atas sengketa-sengketa perbatasan 
antara negara-negara ASEAN dan merumuskan suatu traktat penyelesaian sengketa atas dasar pertimbangan hukum, agar supaya sengketa-sengketa perbatasan antar negara anggota dapat diselesaikan di lingkungan ASEAN sendiri, sehingga penggunaan Pasal 33(1) PBB untuk menyelesaikannya hanya merupakan tindakan darurat saja

\section{Gambar 3. Mekanisme Penyelesaian Sengkera/Konflik Perbatasan di Negara Anggota ASEAN}

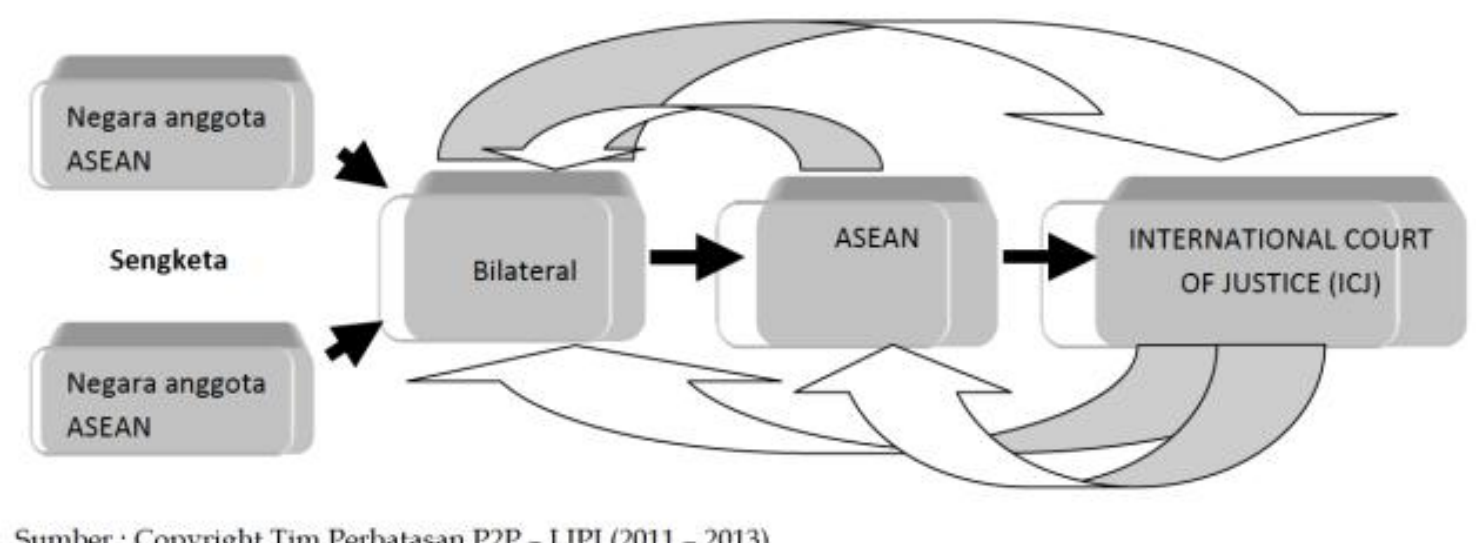

Sumber : Copyright Tim Perbatasan P2P - LIPI (2011 - 2013)

\section{Daftar Rujukan}

Thongchai Winichakul, "Siam Mapped. The Making of Thai Nationhood", The Ecologist, Vol 26, No. 5, September/October 1996

Pavin Chachavalpongpun, "Thailand-Myanmar Relations: Old Animosity in a New Setting", N. Ganesan dan Ramses Amer, International Relations in Southeast Asia. Between Bilateralism and Multilateralism, (Singapore: Institute of Southeast Asia Studies, 2010)

Aung Saw, "ASEAN-Burma Relations". Challenges to Democratisation in Burma, http://www.idea.int/asia_pacific/burma/upload/chap1.pdf

Marvin Ott, "From Isolation to Relevance: Policy Considerations" in Burma: Prospects for Democratization, Washington: Brookings Institute Press, 1998

Kavi Chongkittavorn, "Understanding new Thai policy towards Burma", Regional Perspective, The Nation, 5 Januari 2009

Boundaries:ABriefingNoteonthe Cambodian-ThaiBorder Tensions, July 2011, Cambodian Center for Human Rights, http://www.cchrcambodia.org/admin/media/analysis/analysis/english/Blu rred \%20Boundaries \%20\%20A\%20Briefing\%20Note\%20on \%20the\%20CambodianThai\%20Border\%20Tensions.pdf 
Thitinan Pongsudhirak, Chulalongkorn University, "Domestic determinants of the Thai-Cambodian dispute", East Asia Forum, May 18th, 2011,http:// www.eastasiaforum.org/2011/05/18/domestic-determinants-ofthe-thai-cambodian-dispute/

Ronald Bruce St John, Preah Vihear and the Cambodia-Thailand Borderland, http://www.dur.ac.uk/resources/ibru/publications/full/bsb1-4_john.pdf, 8 Agustus 2011

Suthichai Yoon, "Demilitarised Zone versus de-politicised approach", The Nation, 28 Juli 2011

Pou Sothiarak, "Preah Vihear Dispute Put ASEAN's Effectiveness to Test", Viewpoints, http://web1.iseas.edu.sg/?p=2958, diunduh 26 Agustus 2011

ISEAS Executive Summary Seminar on "ASEAN and Thai-Cambodian Conflict from Historical,Current and Regional Perspectives", 24 February 2011, http:/ / web1.iseas.edu.sg/?p=2663, diunduh 7 Agustus 2011

Peter Janssen and Robert Carmichael DPA, ANALYSIS: Domestic politics muddy Thai-Cambodian border spat, 9 Februari 2011, http://kimedia.blogspot.com/2011/02/analysis-domestic-politics-muddy-thai.html

Pavin Chachavalpongpun, The Disputed Thai-Cambodia Border, Ceri Science-Po, http://www.ceri-sciencespo.com/archive/2011/mai/art_pc.pdf, diunduh 26 Juli 2011

Thailand and Cambodia: Time for ASEAN to Act. Posted by Michael Vatikiotis, February 25, 2010, MacArthur Foundation, Asia Security Initiative Blog, http://asiasecurity.macfound.org/blog, diunduh 7 Agustus 2011

Craig Guthrie, "Cambodia rattles Thailand's chain", Asia Times Online, 10 November 2009, http://www.atimes.com/atimes/Southeast_Asia/KK10Ae01.html

Historic Firsts: ASEAN Efforts on Cambodian-Thai Conflict Endorsed by UNSC, Official Website of the Association of Southeast Asian Nations, 21 Februari 2011, http://www.aseansec.org/25924.htm

Edith M. Lederer, UN Urges Peaceful Thai-Cambodia Settlement, The Irrawady, 15 Februari 2011, http://www.irrawaddy.org/article.php?art_id=20757 , diunduh 7 Agustus 2011

Tamara Lam-Plattes, The Temple Torn Between Two Nations: A Legal and Political Analysis of the On-Going Conflict Over the Preah Vihear Temple on the Cambodian-Thai Border, University of San Francisco School of Law, 2010, www.usfca.edu/law/docs/templetorn/ Diunduh 18 Juni 2013

Captain Soonpuen Somapee, Insurgency In Southern Thailand And The Four-Track Mitigation

Policy, http://www.navy.mi.th/navedu/acd/data_docu/capt_soonpuen_somapee/s outhern thailand.pdf

Imtiyaz Yusuf, "The Southern Thailand Conflict and the Muslim World," http://www.bangkokbiznews.com/2006/special/south/pdf/southern01.pdf 
Rita Camilleri, "Muslim Insurgency in Thailand and The Philippines: Implications for Malaysia's Cross-Border http://www.une.edu.au/asiacentre/PDF/No27.pdf

John Funston, Thailand's Southern Fires: The Malaysian Factor, http://www.une.edu.au/asiacentre/PDF/No26.pdf

Captain Somapee, Insurgency In Southern Thailand And The Four-Track Mitigation Policy,http://www.navy.mi.th/navedu/acd/data_docu/capt_soonpuen_soma pee/southern_thailand.pdf

John Funston, "Malaysia and Thailand's southern conflict: reconciling security and ethnicity," Contemporary Southeast Asia, August 2010

Zachary Abuza, “The Ongoing Insurgency in Southern Thailand: Trends in Violence, Counterinsurgency Operations, and the Impact of National Politics," Institute for National Strategic Studies, Strategic Persepctives 6, http://www.ndu.edu/inss/docuploaded/Strategic\%20Perspectives\%206_Abu za\%20.pdf, 6 June 2012

Ukrist Pathamanand, From to Friends Enemies, http:/ / www.thaiworld.org/en/include/print.php?text=119\&category_id=5\&p rint=true, 5 Juni 2012

Ukrist Pathamanand, "From Friends to Enemies," http:// www.thaiworld.org/en/include/print.php?text=119\&categor y_id=5\&print=true, 5 Juni 2012

Captain Soonpuen Somapee, "Insurgency In Southern Thailand And The Four-Track Mitigation

Policy,"http://www.navy.mi.th/navedu/acd/data_docu/capt_soonpuen_som apee/southern_thailand.pdf, 6 June 2012 
